\title{
Dissolved organic carbon, nitrogen and phosphorus in the N-E Atlantic and the N-W Mediterranean with particular reference to non-refractory fractions and degradation
}

\author{
Alain Aminot* and Roger Kérouel
}

IFREMER-Brest, BP 70, 29280 Plouzané, France

*: Corresponding author : E-mail: aaminot@ifremer.fr; Fax : +33 298224 548; Tel : +33 298224361

\begin{abstract}
:
Dissolved organic carbon (DOC), dissolved organic nitrogen (DON) and dissolved organic phosphorus (DOP) measured in deep profiles in the N-E Atlantic and in the N-W Mediterranean in the period 1984-2002 are described. After accurate validation, they show close agreement with those previously published.

Classic profiles were obtained, with concentrations decreasing in deep waters. In the Mediterranean and in the Atlantic comparable concentrations were found in the 1500-2000 m waters, 44-46 $\mu \mathrm{mol} \mathrm{I}{ }^{-1}$ DOC, 2.6-2.8 $\mu \mathrm{mol} \mathrm{I}^{-1} \mathrm{DON}$ and $0.02-0.03 \mu \mathrm{mol} \mathrm{I}^{-1} \mathrm{DOP}$. In the surface layers, DOC concentrations were higher, but DON and DOP concentrations lower, in the Mediterranean than in the Atlantic, leading to higher element ratios in the Mediterranean. In autumn, values were, respectively, DOC:DON $\approx 17$ vs. $\sim 14$, DOC:DOP $\approx 950$ vs. 500 and DON:DOP $\approx 55$ vs. 35 . The data suggest an increase in DOC and DON in the North Atlantic Central Water over 15 years, which may be linked to the North Atlantic climatic oscillations.

Refractory DOM found in the 1500-2000 m layer exhibited C:N:P ratios of 1570:100:1. The labile+semi-labile (=non-refractory) DOM (nrDOM) pool was computed as DOM in excess of the refractory pool. Its contribution to total DOM above the thermocline in the open sea amounted to 25$35 \%$ of DOC, $30-35 \%$ of DON, and $60-80 \%$ of DOP. Element ratios of the nrDOM varied among stations and were lower than those of refractory DOM, except for C:N in the Mediterranean: nrDOC:nrDON $\sim 10-19$, nrDOC:nrDOP $\sim 160-530$ and nrDON:nrDOP $\sim 15-38$. The specific stoichiometry of DOM in the Mediterranean led us to postulate that overconsumption of carbon is probably a main process in that oligotrophic sea.

By coupling non-refractory DOM stoichiometry and relationships between the main DOM elements in the water column, the relative mineralization of $\mathrm{C}, \mathrm{N}$ and $\mathrm{P}$ from DOM was studied. Below the thermocline, the preferential removal of phosphorus with regard to carbon from the semi-labile DOM can be confirmed, but not the preferential removal of nitrogen. In the ocean surface layers, processes depend on the oceanic area and can differ from deep waters, so preferential carbon removal seems more frequent. Bacterial growth efficiency data indicate that bacteria are directly responsible for mineralization of a high proportion of DON and DOP in the deep water.
\end{abstract}

Keywords: Dissolved organic carbon; Dissolved organic nitrogen; Dissolved organic phosphorus; Refractory; Non-refractory; Mineralization; N-E Atlantic; N-W Mediterranean 


\section{INTRODUCTION}

Dissolved organic matter (DOM) is produced and decomposed by microorganisms in the oceans and contributes to the transfer of production in oligotrophic areas and to deep ocean layers (Christensen et al.,1989; Toggweiler, 1989; Copin-Montégut and Avril, 1993; Emerson et al., 1997; Abell et al., 2000). DOM may also constitute a source of nutrients for primary production where inorganic nitrogen and phosphorus become limiting factors (Berman and Chava, 1999). In addition to biological processes, DOM transformation may result from photoreaction in the surface layer and the subsequent production of some biologically labile compounds (Mopper et al., 1991; Moran and Zepp, 1997), but with an overall reduction in bacterial production (Benner and Biddanda, 1998). Therefore, DOM is an essential link in the processes controlling carbon and nutrient cycling. Since it accounts for about $50 \%$ of the organic matter mass, carbon is an ideal tracer of ocean DOM. Consequently, dissolved organic carbon (DOC) has been widely studied over the last decade.

It is well established that concentrations of DOM are higher in the upper layer than in deep water bodies. In deep waters, organic matter is highly refractory to bacterial mineralization and its residence time is on the order of thousands of years (Bauer et al., 1992). Recent studies, which have produced more reliable concentration values, tend to attribute a narrow range of concentrations around 40-50 $\mu \mathrm{mol} \mathrm{l}^{-1}$ DOC in deep waters over the world ocean. However, comparison of various areas shows that the deep water DOC concentration actually exhibits gradients throughout the world (Hansell and Carlson, 1998).

Several authors have shown that better understanding of the DOM cycle in the oceans requires the coupling of DOC and dissolved organic nitrogen (DON) pools and dynamics (Kirchman et al., 1991; Carlson et al., 1994; Fasham et al., 1999). The elemental composition of DOM is also an indicator of its bioavailability (Hunt et al., 2000; Sun et al., 1997). In order to obtain more complete information on how DOM behaves, it is preferable to evaluate it using the three elements essential to biological processes: dissolved organic carbon (DOC), dissolved organic nitrogen (DON) and dissolved organic phosphorus (DOP).

Despite the increasing number of studies dealing with dissolved organic matter, those including simultaneous measurements of DOC, DON and DOP are rare. This paper uses data mostly obtained in the 1980s and 90s, when there was considerable concern about the measurement of DOC and DON (Suzuki et al., 1985; Sugimura and Suzuki, 1988; Toggweiler, 1988; Williams and Druffel, 1988; Sharp, 1993). Then international research on DOC, DON and DOP determinations (Special Issue of Marine Chemistry 41, 1993) and subsequent intercomparisons (Sharp, et al., 1995; Peltzer et al., 1996) led to the conclusion that older data could be trusted, provided that methods were carefully corrected for artifacts (mainly blanks) and checked (Sharp, 1997). Accordingly, our results were completely reexamined in the light of recent advance in methods, and now constitute a consistent set of comparable data. It is important to note that, over the study period, DON was measured using a single method, as was DOP, and DOC was measured using two closely intercompared methods. This data set allowed the first comparison of DOM stoichiometry from vertical profiles in the Bay of Biscay (N-E Atlantic) and from the northwestern Mediterranean to be made. These oceanic bodies exchange water through the strait of Gibraltar, and Mediterranean water influences the vertical hydrography in the N-E Atlantic. The paper will focus on several aspects that may influence DOM concentration and stoichiometry, giving particular attention to the non-refractory pool of DOM in terms of concentration and mineralization. 


\section{MATERIAL AND METHODS}

\subsection{Study area main characteristics}

The area of study and sampling stations are described in Figure 1 and Table 1. DOC, DON and DOP could be measured simultaneously at three profiles in the Atlantic (stations A1, A2 and A3) and one profile in the Mediterranean (station M). Because it is more difficult to measure DOP precisely, additional DOP results are provided from two other profiles in the Atlantic (stations A4 and A5).

Table 1. Characteristics of sampling stations.

\begin{tabular}{|c|c|c|c|c|c|c|}
\hline Station & Area & Date & Position & $\begin{array}{c}\text { Bottom } \\
\text { depth } \\
\text { m }\end{array}$ & $\begin{array}{c}\text { Deepest } \\
\text { sample } \\
\text { m }\end{array}$ & $\begin{array}{l}\text { Cruise } \\
\text { name }\end{array}$ \\
\hline \multirow[t]{2}{*}{ A1 } & N-E Atlantic & 10 Sept. 1985 & $43^{\circ} 38.0 \mathrm{~N}$ & 900 & 850 & Intersite 3 \\
\hline & Bay of Biscay & & $1^{\circ} 52.2^{\prime} \mathrm{W}$ & & & \\
\hline \multirow[t]{2}{*}{$\mathrm{A} 2$} & N-E Atlantic & 20 April 2002 & $46^{\circ} 45.0^{\prime} \mathrm{N}$ & 4240 & 4000 & Gasprod \\
\hline & Bay of Biscay & & $5^{\circ} 59.6^{\prime} \mathrm{W}$ & & & \\
\hline \multirow[t]{2}{*}{ A3 } & N-E Atlantic & 26 Oct. 1987 & $46^{\circ} 00.0^{\prime} \mathrm{N}$ & 4200 & 3500 & Intersite 4 \\
\hline & Bay of Biscay & & $6^{\circ} 01.6^{\prime} \mathrm{W}$ & & & \\
\hline \multirow[t]{2}{*}{ A4 } & N-E Atlantic & 24 July 1990 & $46^{\circ} 11.9^{\prime} \mathrm{N}$ & 4780 & 1500 & Gastom 3 \\
\hline & Bay of Biscay & & $9^{\circ} 10.0^{\prime} \mathrm{W}$ & & & \\
\hline \multirow[t]{2}{*}{ A5 } & N-E Atlantic & 25 July 1990 & $45^{\circ} 01.9 \mathrm{~N}$ & 4875 & 1500 & Gastom 3 \\
\hline & Bay of Biscay & & $9^{\circ} 55.1 \mathrm{~W}$ & & & \\
\hline \multirow[t]{2}{*}{ M } & $\mathrm{N}-\mathrm{W}$ & 13 Sept. 1984 & $42^{\circ} 02.4^{\prime} \mathrm{N}$ & 2500 & 1500 & Intersite 2 \\
\hline & Mediterranean & & $5^{\circ} 04.8^{\prime} \mathrm{E}$ & & & \\
\hline
\end{tabular}

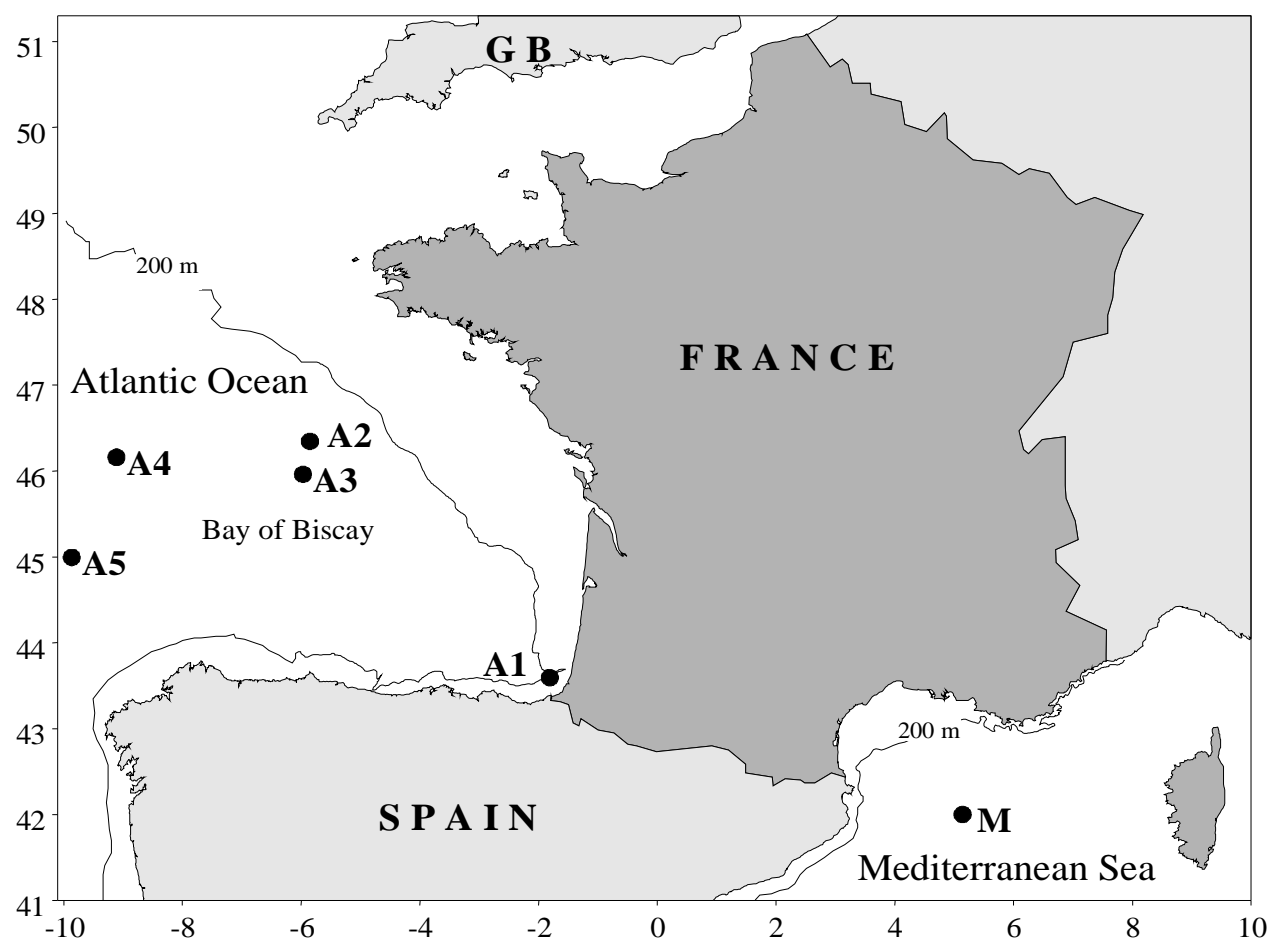

Figure 1. Location of sampling stations. 


\section{$N$ E Atlantic}

The water masses have been widely described (e.g., Vangrieshem, 1985; Arhan et al., 1994). In winter, the upper layer (0-700 m) of North Atlantic Central Water (NACW) is mixed by intense convection. In spring, NACW begins to be capped by a seasonal thermocline, isolating North Atlantic Surface Water (NASW) of variable salinity and temperature (max. depth $100 \mathrm{~m}$ ). A marked pycnocline separates NACW from the North Atlantic Mediterranean Water (NAMW) plume identified by the salinity maximum (800$1200 \mathrm{~m}$ ). Labrador water lies around $1800 \mathrm{~m}$ and Norwegian Sea water around $2000 \mathrm{~m}$. Below 2000 m, the North Atlantic Deep Water (NADW) coming from Greenland is influenced by the all-pervading diluted Atlantic Antarctic Bottom Water (AABW).

Mediterranean Sea

The three-layer system found in this sector has been well documented (e.g., Wüst, 1961; Lacombe, 1975). The core water masses are i) the less saline, upper layer (MUL) water of Atlantic origin $(\sim 0-75 \mathrm{~m})$, ii) the more saline, intermediate water of eastern origin (MIEW; $\sim 200-600 \mathrm{~m}$ ) and iii) the deep Mediterranean water (DMW) below $1500 \mathrm{~m}$.

\subsection{Sampling and storage}

Water was sampled in 5 or 8 liter Niskin bottles. Subsamples were collected for salinity in glass bottles with rubber sealed porcelain caps and for nutrients in $125 \mathrm{ml}$ polyethylene bottles pretreated with $10 \% \mathrm{HCl}$. For DOM, samples were collected in $500 \mathrm{ml}$ precombusted glass bottles, and subsequently filtered within half an hour onboard the ship. After vacuum (max. 0.3 bar) filtration through precombusted $\left(480^{\circ} \mathrm{C}\right.$ ) Whatman $\mathrm{GF} / \mathrm{F}$ glass-fiber filters, the subsamples were collected in precombusted glass bottles stoppered with linerless polyethylene screwcaps ( $35 \mathrm{ml}$ for DOC measured by high temperature combustion, $125 \mathrm{ml}$ for DOC measured by wet oxidation and $125 \mathrm{ml}$ for DON+DOP). The subsamples for nutrients and DOM were immediately stored in upright position in a freezer $\left(-20\right.$ to $\left.-25{ }^{\circ} \mathrm{C}\right)$ used only for water samples. Freezing of non-acidified samples of seawater has already been shown to be a reliable preservation technique up to 5-6 months (Walsh, 1989; Williams et al., 1993; Tupas et al., 1994). Analysis was performed in the shore laboratory within a few months of collection, and within one hour after samples were thawed in a cold tap water bath and then well mixed.

\subsection{Temperature, salinity and nutrient measurements}

Temperature was measured using reversing thermometers before the 1990s, later using in situ probes. Salinity (in PSS78) was measured soon after the cruise with a Guildline 8400 or 8410 salinometer. Ammonium (before the 2002 cruise), nitrate+nitrite $(\mathrm{N} \& N)$, phosphate and silicate were measured using the classic colorimetric methods adapted to segmented flow analysis (Technicon Autoanalyzer II) according to Tréguer and Le Corre (1975). For the 2002 cruise, ammonium was measured according to Kérouel and Aminot (1997).

\subsection{DOC measurement}

Measurements were performed up to 1989 using an automated wet oxidation (WO) method including direct intake from the sample bottle (no decanting), automated inorganic carbon removal, hot acidic persulfate plus UV-alkaline oxidations and colorimetric $\mathrm{CO}_{2}$ determination (Aminot and Kérouel, 1990). The high temperature combustion (HTC) instrument (Shimadzu TOC 500) used subsequently was equipped with an ASI 502 automatic sample injector. Inorganic carbon was eliminated shortly before analysis by adding $250 \mu 1$ $\mathrm{HCl} 1.2 \mathrm{~mol} \mathrm{l}^{-1}$ directly to the whole sample $(30 \mathrm{ml})$ contained in the sample bottle and

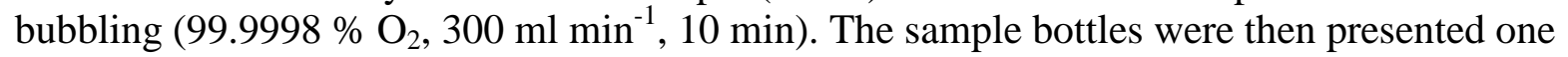


by one to the automatic injector's syringe, with the carrousel removed to avoid sample transfers, and each sample was injected at least three times. The Shimadzu High Sensitivity catalyst (platinized quartz wool, P/N 630-00958, topped with 10 platinum grids) was used. The catalyst was renewed well before it became what Peltzer and Brewer (1993) called "saltimpregnated dust". Since Cauwet et al. (1990) and Peltzer and Brewer (1993) suspected that platinized quartz wool (PQW) oxidized less DOC than other catalysts, the performances of PQW and a $4.5 \%$ Pt-alumina catalyst (provided by Shimadzu-France) were compared. MilliQ water solutions of organic compounds (sulfathiazol, antipyrine, thiourea, L-methionine, Lcysteine, L-tryptophan, nicotinic acid, fulvic acid, humic acid, starch, albumin, chitin, polyethyleneglycol; $\sim 170 \mu \mathrm{mol} \mathrm{l}^{-1} \mathrm{C}$ ) and natural seawater led to comparable $( \pm 3 \%)$ or even better recoveries (range 80-100 \%) with PQW. Additionally, PQW ageing was checked by analyzing 18 natural samples (40-80 $\mathrm{mol} \mathrm{l}^{-1}$ DOC) twice, first after 70 then after 275 seawater analyses (meantime, the samples were stored tightly capped in a closed metal box). At the significance level of $\alpha=0.05$ a two-sided Student t-test showed that DOC recoveries were identical $(\mathrm{t}=1.4$ compared to critical- $\mathrm{t}=2.1)$.

Freshly drawn demineralized water, from a Milli-Q system equipped with an Organex cartridge, was used as blank. In the continuous flow WO method, $\mathrm{UV} / \mathrm{H}_{2} \mathrm{O}_{2}$-treated natural or artificial seawater was used to overcome artifacts, but specific corrections were made to refer to Milli-Q. Compared with $\mathrm{UV} / \mathrm{H}_{2} \mathrm{O}_{2}$-treated water, fresh Milli-Q water was found to be organic-free within the detection limit of our DOC methods $\left(<3 \mu \mathrm{mol} \mathrm{l}^{-1}\right)$. This agrees with data on Milli-Q water's carbon content (Sharp et al., 1993). In the HTC method, the total blank is mainly a system blank (overall range: 6-15 $\mu \mathrm{mol} \mathrm{l}^{-1}$ DOC). Daily blank variations were smooth, with standard deviations $<2 \mu \mathrm{mol} \mathrm{l}^{-1}$. Interpolation of individual sample blanks between blank measurements decreased blank uncertainty to within $\pm 1 \mu \mathrm{mol} 1^{-1}$. With blank reference material provided by Dr J.H. Sharp, the DOC equivalent total system signal ranged from 7 to $11 \mu \mathrm{mol}^{-1}$ (1997 to 2002), while the actual DOC concentration found in the RM was $0.9 \pm 0.8 \mu \mathrm{mol} \mathrm{l}^{-1}$ (10 samples). The stability of the HTC response was checked over the period from 1999 to 2002 with the deep ocean reference material provided by J. Sharp: the concentration found was $47.4 \pm 1.9 \mu \mathrm{mol} \mathrm{l}^{-1}$ (7 samples).
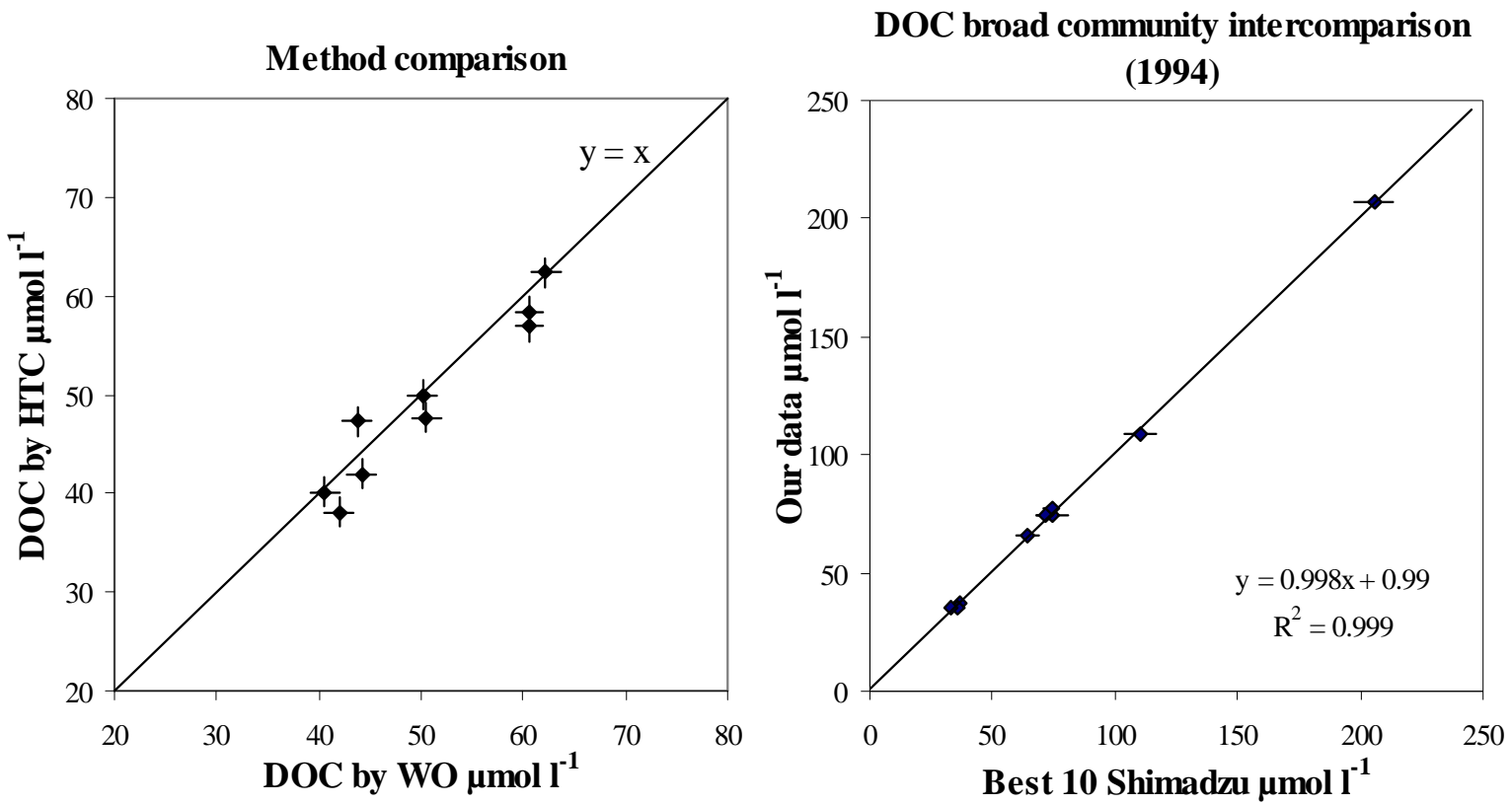

Figure 2. DOC data comparison. Left: laboratory comparison of our WO and HTC results (with standard deviation) using samples from station A3. Right: broad community intercomparison 1994, our data vs the 10 best Shimadzu (with standard deviation). 
Our WO and HTC methods were compared using 9 samples from the 1987 deep Atlantic profile A3 (Figure 2). A two-sided Student t-test showed that DOC determinations by WO and HTC did not differ $(\mathrm{t}=1.7$ compared to critical- $\mathrm{t}=2.3 ; \alpha=0.05)$. Our results in the 1994 broad community intercalibration compared well with the ten best Shimadzu averages (Sharp et al., 2002; Figure 2). The comparability of our WO and HTC results, along with the agreement of our HTC results with international data, validates our whole DOC data set.

\subsection{DON measurement}

The persulfate WO method developed by Solorzano and Sharp (1980) was considered to be the most suitable and reliable for TDN determination, since it ensures complete recovery of nitrogen from recalcitrant compounds. DON resulted from the difference between total dissolved nitrogen (TDN) and dissolved inorganic nitrogen (nitrate + nitrite + ammonium) measured in the same run, just before sample oxidation, from the same sample bottle. The method was applied with the following minor modifications. Using automatic pipettes, aliquots of $10 \mathrm{ml}$ (instead of $40 \mathrm{ml}$ ) were used and reagents added proportionally. To resist pressure, screw-cap $25 \mathrm{ml}$ borosilicate glass bottles with PTFE-coated silicone liners (Duran Schott, GL 25) were selected (instead of all Teflon vials). The oxidation vials (new or unutilized for some time) were cleaned as follows: rinsed with Milli-Q water, pyrolyzed at $500{ }^{\circ} \mathrm{C}$, put through a normal procedure run with Milli-Q water as a sample and finally rinsed and capped. Just before use, the reaction vessel was rinsed with freshly drawn Milli-Q water and thoroughly shaken dry. The vials were autoclaved with caps tightly closed (instead of unscrewed) to avoid evaporation and potential contamination from the atmosphere. The last step of the original procedure, buffering before measuring nitrate, was omitted since the high dilution by the buffer reagent in our automated nitrate method (Tréguer and Le Corre, 1975) enabled direct analysis of the acidified samples. Clogging of the $\mathrm{Cd}-\mathrm{Cu}$ reduction column, which Solorzano and Sharp (1980) attributed to insoluble silica released from glass vials, was not observed because of rapid settling of particles, followed by high dilution of the supernatant in the manifold. These modifications decreased the blank significantly and improved the overall precision of DON data. Determining the nitrate in the non-oxidized and oxidized samples in the same run (same calibration curve) also enhanced reliability.

DON analysis periods started by systematically checking blank repeatability in all the bottles used for that series and repeating the process until the variability stabilized at usual values $\left(\sim 1-1.5 \pm 0.05-0.1 \mu \mathrm{mol} \mathrm{l}^{-1}\right)$. To each daily series of $\sim 30$ natural samples, several blanks were added, as well as standards of nitrate and/or ammonia and/or urea or amino-acids, in order to check recovery. Many (when not all) samples were analyzed in duplicate.

Walsh (1989) and Bronk et al. (2000) reported that persulfate oxidation and HTC can provide reproducible results that are consistent with each other. This was confirmed by a recent international intercomparison (Sharp et al., 2002).

\subsection{DOP measurement}

The photo-oxidation automated method used for DOP + soluble reactive phosphate (SRP) determination (Aminot and Kérouel, 2001) included direct intake from the sample bottle (no decanting), UV-peroxide oxidation and colorimetric SRP determination. DOP was obtained by subtracting SRP measured simultaneously in a parallel channel (according to Tréguer and Le Corre, 1975), from the same sample bottle. Digestion of labile and refractory DOP model compounds was virtually complete when compared with that of the alkaline persulfate oxidation (Koroleff, 1983) as a reference method (Kérouel and Aminot, 1996). Freshly drawn Milli-Q water was used as the zero-P reference and the refractive index blank (RIB) was subtracted systematically. For RIB determination, samples were re-run using a 
reagent devoid of molybdenum and antimony salts to prevent color development (Tréguer and Le Corre, 1975; Loder and Glibert, 1977).

\subsection{Quality control, accuracy and precision}

The data set was entirely re-assessed in the light of more recent improvements or knowledge in methods. A few minor blank corrections were subsequently made (in particular for WO-DOC) and uncertainties on DOC, DON and DOP were specifically determined for each series.

Of the many definitions proposed for accuracy (Massart et al., 1988), one generally accepted is "the degree of agreement of a measured value with the true or expected value of the quantity of concern" (Taylor, 1990). There is presently no absolute way of determining the true value of DOC, DON and DOP in seawater, therefore agreement with expected values through intercomparisons is the only recourse. Our DOC results were found to be in satisfactory agreement with international data (Figure 2), but DON and DOP did not benefit from such intercomparisons. The recent TDN broad community intercomparison (Sharp et al., 2002) provided only a partial view of DON, since few participants provided DIN data and a unique DIN value had to be subtracted from participants' TDN data. No broad community intercomparison has ever been specifically undertaken for DOP.

Table 2. Precision of DOC, DON and DOP for the data series taken into consideration.

\begin{tabular}{|c|c|c|c|c|c|c|}
\hline \multirow[b]{2}{*}{ Parameter } & \multirow[b]{2}{*}{ Data } & \multicolumn{5}{|c|}{$\begin{array}{l}\text { Station } \\
\text { (date) }\end{array}$} \\
\hline & & $\begin{array}{c}\mathrm{A} 1 \\
(09 / 85) \\
\end{array}$ & $\begin{array}{c}\mathrm{A} 2 \\
(04 / 02) \\
\end{array}$ & $\begin{array}{c}\text { A3 } \\
(09 / 87) \\
\end{array}$ & $\begin{array}{r}\text { A4, A5* } \\
(07 / 90)\end{array}$ & $\begin{array}{c}\mathrm{M} \\
(09 / 84)\end{array}$ \\
\hline \multirow[t]{4}{*}{ DOC } & Method & WO & HTC & WO & - & WO \\
\hline & Sample number (nb from profile) & $19(3)$ & $18(18)$ & $16(16)$ & - & $9(5)$ \\
\hline & Concentration range, $\mu \mathrm{mol} \mathrm{l}^{-1}$ & $46-86$ & $42-78$ & $41-62$ & - & $43-70$ \\
\hline & Standard deviation, $\mu \mathrm{mol} \mathrm{l}^{-1}$ & 1.8 & 1.6 & 1.4 & - & 1.2 \\
\hline \multirow[t]{5}{*}{ DON** } & $\mathrm{TDN}<12 \mu \mathrm{mol} \mathrm{l}^{-1}$ & & & & & \\
\hline & Sample number (nb from profile) & $12(2)$ & $10(5)$ & $10(2)$ & - & $22(5)$ \\
\hline & $\begin{array}{l}\text { Standard deviation, } \mu \mathrm{mol} \mathrm{l}^{-1} \\
\text { TDN }>12 \mu \mathrm{mol} \mathrm{l}^{-1}\end{array}$ & 0.07 & 0.07 & 0.08 & - & 0.07 \\
\hline & Sample number (nb from profile) & $4(1)$ & $8(8)$ & $11(0)$ & - & - \\
\hline & Standard deviation, $\mu \mathrm{mol} 1^{-1}$ & 0.09 & 0.08 & 0.11 & - & - \\
\hline \multirow[t]{5}{*}{$\mathrm{DOP}^{* *}$} & $\mathrm{TDP}<0.5 \mu \mathrm{mol} \mathrm{l}^{-1}$ & & & & & \\
\hline & Sample number (nb from profile) & $17(3)$ & $5(5)$ & $8(5)$ & $10(5)$ & $15(0)$ \\
\hline & $\begin{array}{l}\text { Standard deviation, } \mu \mathrm{mol} \mathrm{l}^{-1} \\
\text { TDP }>0.5 \mu \mathrm{mol} \mathrm{l}^{-1}\end{array}$ & 0.012 & 0.004 & 0.011 & 0.006 & 0.009 \\
\hline & Sample number (nb from profile) & $5(3)$ & $8(8)$ & $11(11)$ & $13(13)$ & - \\
\hline & Standard deviation, $\mu \mathrm{mol} \mathrm{l}^{-1}$ & 0.014 & 0.005 & 0.011 & 0.006 & - \\
\hline
\end{tabular}

$*$ A4 and A5 samples analyzed in the same series.

** Corresponding depths for TDN $<12 \mu \mathrm{mol}^{-1}$ and TDP $<0.5 \mu \mathrm{mol} \mathrm{l}^{-1}$ : M, whole water column; A1, < $80 \mathrm{~m} ; \mathrm{A} 2,<200 \mathrm{~m} ; \mathrm{A} 3, \mathrm{~A} 4$ and A5, < $150 \mathrm{~m}$.

Our data's precision (Table 2) was determined from duplicate analyses of samples as described below, and computed according to Taylor (1990). 
For DOC, analyzed samples were re-capped, stored in a clean place then measured again, generally the same day (samples analyzed by HTC were re-bubbled). Comparable standard deviations of about $1.5 \mu \mathrm{mol} \mathrm{l}^{-1}$ were found throughout the study period (Table 2).

To obtain DON precision, two aliquots of each sample were submitted to oxidation while nitrate+nitrite $(\mathrm{N} \& \mathrm{~N})$ and ammonium were determined in the remaining sample, then the two oxidized aliquots were measured successively for TDN. Total variance of DON was computed as the sum of the contributions from its individual analytical components (Taylor, 1990). From DON $=$ TDN $-N \& N-$ ammonium, it comes: $s^{2}{ }_{D O N}=s^{2}{ }_{T D N}+s^{2} \& N+s^{2}$ ammonium. TDN and N\&N were measured within the same series, using the same manifold, hence contribution of $\mathrm{N} \& \mathrm{~N}$ to uncertainty was restricted to its short-term repeatability component, i.e., $\sim 0.1 \%$ of concentration (and $\geq 0.01 \mu \mathrm{mol} \mathrm{l}^{-1}$ ) with our Autoanalyzer (Aminot and Kérouel, 1995). The overall standard deviation of $0.02 \mu \mathrm{mol}^{-1}$ was used for all $\mathrm{N} \& \mathrm{~N}$ concentrations encountered. For ammonium, the uncertainty in the concentration range encountered $\left(<0.6 \mu \mathrm{mol} \mathrm{l}^{-1}\right)$ was correctly reflected using a standard deviation of $0.02 \mu \mathrm{mol} \mathrm{l}^{-1}$ (Aminot and Kérouel, 1995, 1996). DON standard deviations were computed in the low $\left(<12 \mu \mathrm{mol} \mathrm{l}^{-1}\right)$ and in the high $\left(>12 \mu \mathrm{mol} \mathrm{l}^{-1}\right)$ TDN range (Table 2$)$. The concentration level did not have a marked effect, and standard deviations did not exceed 0.08 $\mu \mathrm{mol} \mathrm{l}^{-1}$ and $0.11 \mu \mathrm{mol} \mathrm{l}^{-1}$, respectively, in the low and high TDN ranges.

DOP duplicate samples from the same bottle or from two different bottles provided similar precision. Standard deviations computed for DOP (= TDP - SRP) included variability from both TDP and SRP analyses, since these were systematically measured in parallel in each sample using two independent manifolds. DOP standard deviations, computed for the low $\left(<0.5 \mu \mathrm{mol} \mathrm{l}^{-1}\right)$ and the high $\left(>0.5 \mu \mathrm{mol} \mathrm{l}^{-1}\right)$ TDP ranges show little influence of the TDP range (Table 2): $\leq 0.012 \mu \mathrm{mol}^{-1}$ in the low range and $\leq 0.014 \mu \mathrm{mol} \mathrm{l}^{-1}$ in the high range. This is attributed to the high repeatability of the Autoanalyzer and the use of the same phosphate standards to simultaneously calibrate the TDP and the SRP channels. Variability decreased at stations A2, A4 and A5 $\left(\leq 0.006 \mu \mathrm{mol} \mathrm{l}^{-1}\right)$ due to computer peak recording and processing (replacing paper recording of older data). Results (in $\mu \mathrm{mol}^{-1}$ ) were processed to three decimal figures and then rounded to the second decimal figure in most tables.
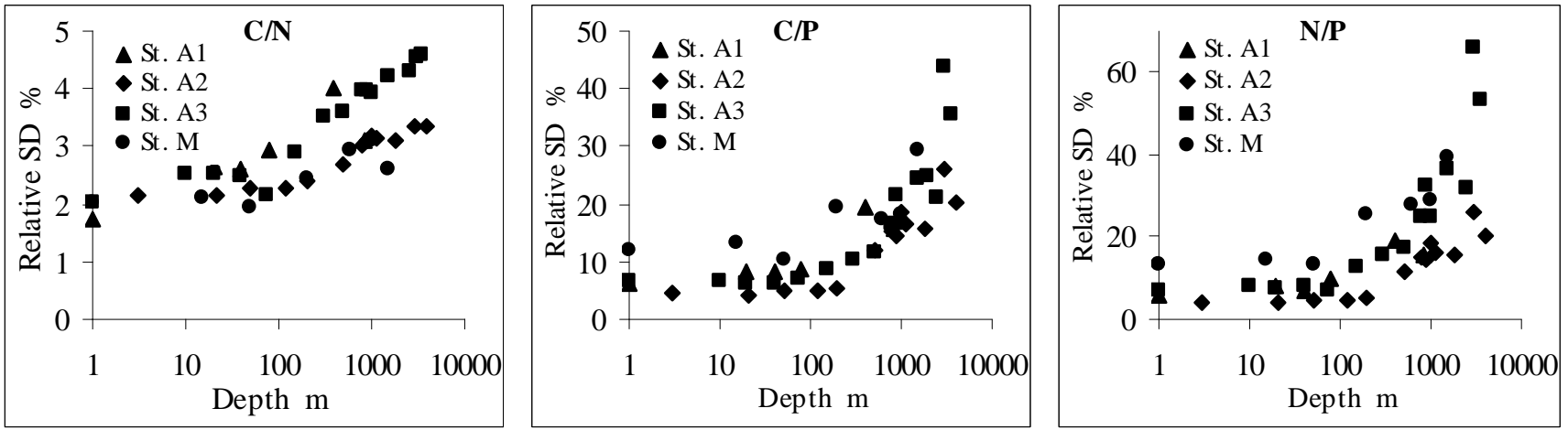

Figure 3. Relative standard deviations of DOM element ratios as a function of depth.

The standard deviations of element ratios $(\mathrm{C}: \mathrm{N}, \mathrm{C}: \mathrm{P}, \mathrm{N}: \mathrm{P})$ were estimated by the method usually applied to a sample of size ' $n$ ' for which two characteristics ' $x$ ' and ' $y$ ' are measured (Cochran, 1977). Given that $R=\bar{y} / \bar{x}$, the variance is $s_{R}^{2}=\left(1 / n \bar{x}^{2}\right)\left(s_{y}{ }^{2}+R^{2} s_{x}{ }^{2}-2 R s_{x y}\right)$. When applied to our results the covariance term $\left(-2 \mathrm{Rs}_{\mathrm{xy}}\right)$ drops since ' $\mathrm{x}$ ' and ' $\mathrm{y}$ ' were derived from separate analyses. The variances $\mathrm{s}_{\mathrm{x}}{ }^{2}$ and $\mathrm{s}_{\mathrm{y}}{ }^{2}$ were obtained from the series of duplicate analyses. The sample size ' $n$ ' here is the number of determinations in each water sample. Since characteristics ' $x$ ' and ' $y$ ' may or may not have been duplicated, a weighted 
sample size, $\mathrm{n}=\left(\mathrm{n}_{\mathrm{x}} \cdot \mathrm{n}_{\mathrm{y}}\right)^{0.5}$ had to be used. (Note that $\mathrm{n}_{\mathrm{x}}$ and $\mathrm{n}_{\mathrm{y}}$ may be weighted values when ' $\mathrm{x}$ ' and ' $\mathrm{y}$ ' result from differences, e.g., for non-refractory DOM.) The standard deviations of element ratios increase as a function of the decrease in DOM concentration, i.e., with depth (Figure 3).

Hereafter, significance levels are considered for $\alpha=0.05$.

\section{RESULTS}

\subsection{Salinity, temperature and nutrients}

\section{$N$ E Atlantic}

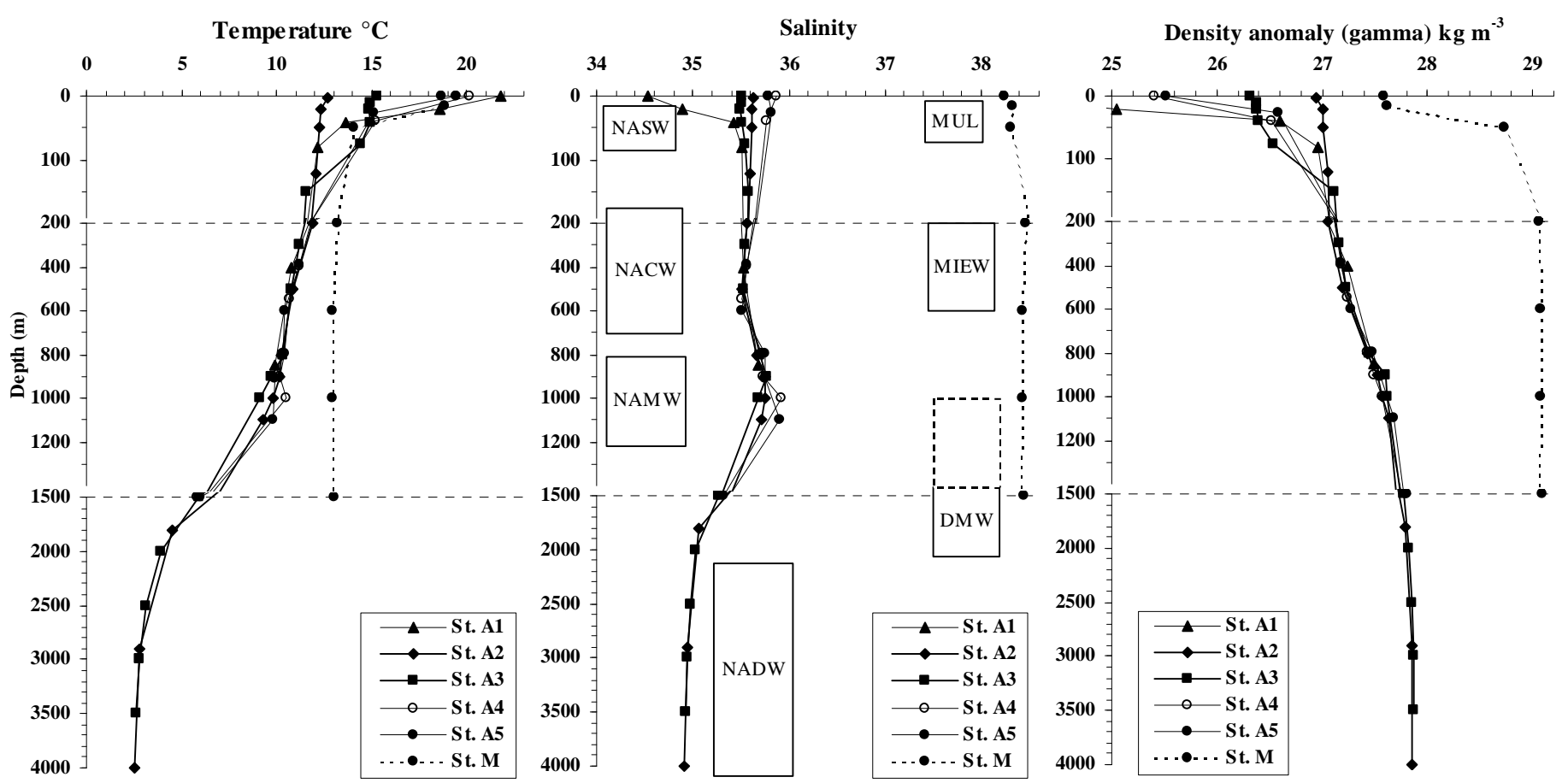

Figure 4. Vertical profiles of temperature, salinity and density anomaly in the N-E Atlantic and in the N-W Mediterranean. Note the different scales as a function of depth. Typical water bodies are given: NASW: North Atlantic Surface Water,

NACW: North Atlantic Central Water,

NAMW: North Atlantic Mediterranean Water,

NADW: North Atlantic Deep Water,

MUL: Mediterranean Upper Layer,

MIEW: Mediterranean Intermediate Eastern Water,

DMW: Deep Mediterranean Water.

A marked thermocline (Figure 4) lay in the 20-50 m layer in summer at the coastal station $\mathrm{A} 1\left(\Delta \mathrm{t} \sim 9{ }^{\circ} \mathrm{C}\right)$ and at open sea stations $\mathrm{A} 4$ and $\mathrm{A} 5\left(\Delta \mathrm{t} \sim 5^{\circ} \mathrm{C}\right)$. At station A2 (early spring), the thermocline was starting $\left(\Delta \mathrm{t} \sim 0.3{ }^{\circ} \mathrm{C}, 13 \mathrm{~m}\right)$, while at station $\mathrm{A} 3$ (early autumn) the thermocline was deeper and disappearing $\left(\Delta \mathrm{t} \sim 3{ }^{\circ} \mathrm{C}, 80-100 \mathrm{~m}\right)$. In deeper layers, the temperature decreased continuously, reaching $\sim 2.5^{\circ} \mathrm{C}$ at $4000 \mathrm{~m}$. In open sea, bottom salinity $(\mathrm{S}=34.9$ at $4000 \mathrm{~m})$ was lower than surface salinity $(\mathrm{S}=35.5-35.9)$ and the intermediate NAMW maximum at $900-1000 \mathrm{~m}$ was marked $(\mathrm{S} \sim 35.8)$. The influence of continental inputs was noted at station A1 (surface $S=34.5$ ). The structure of the water column (Figure 4) showed that vertical advection between water bodies was restricted by two density gradients, 
the seasonal upper thermocline and the main pycnocline between NACW and NAMW. The continuous T-S diagram made at station A2 provides a typical example of water mass structure (Figure 5). At the other stations, the T-S diagram differed in the upper layer (> $150 \mathrm{~m}$ ), with higher temperature (all stations) and lower salinity (st. A1).

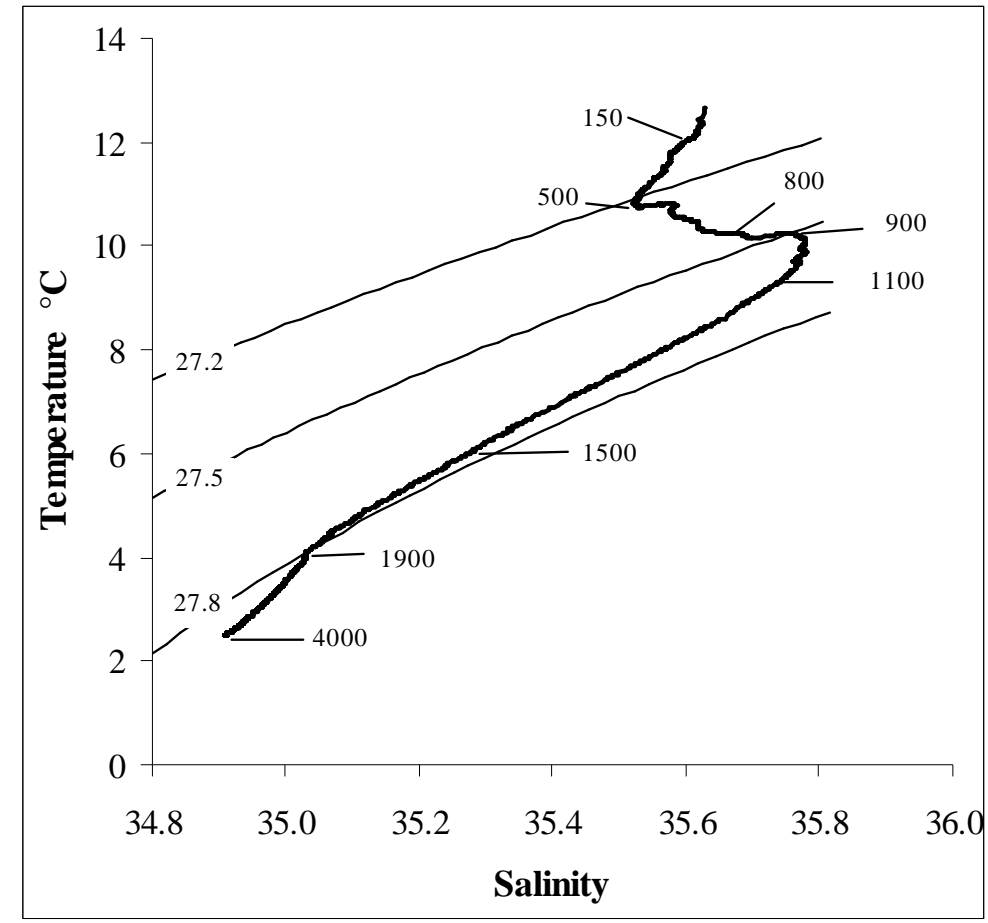

Figure 5. Temperature-Salinity diagram at station A2 in the N-E Atlantic. Some depths are indicated and isodensity lines are drawn for $\gamma=27.2,27.5$ and $27.8 \mathrm{~kg} \mathrm{~m}^{-3}$.

Inorganic nutrients (Figure 6) showed classic profiles with low concentrations above the thermocline and a marked gradient across this boundary. Above the thermocline, nitrate and phosphate concentrations dropped from respectively about $3 \mu \mathrm{mol} \mathrm{l}^{-1}$ and $0.2 \mu \mathrm{mol}^{-1}$ in April to less than $0.3 \mu \mathrm{mol} \mathrm{l}^{-1}$ and $0.01 \mu \mathrm{mol} \mathrm{l}^{-1}$ in summer. Silicate concentrations increased regularly, moving downward under the influence of the rich Antarctic water $\left(\sim 120 \mu \mathrm{mol} \mathrm{l}^{-1}\right)$. The concentration of $45 \mu \mathrm{mol} \mathrm{l}^{-1}$ at $4000 \mathrm{~m}$ indicates about $30 \%$ of AABW in NADW.

Mediterranean Sea

The overall cruise was described by El Sayed et al. (1994). The seasonal thermocline (Figure 4) was still marked in September in the $15 \mathrm{~m}$ upper layer $\left(\sim 19^{\circ} \mathrm{C}\right)$. The temperature dropped rapidly down to $50 \mathrm{~m}\left(\Delta \mathrm{t} \sim 5^{\circ} \mathrm{C}\right)$ reaching an almost constant value $\left(\sim 13{ }^{\circ} \mathrm{C}\right)$ below $200 \mathrm{~m}$. Salinity (higher than in the Atlantic; Figure 4) showed the classic subsurface minimum and a maximum around $200 \mathrm{~m}$ (Lacombe, 1975). The system exhibited an almost constant density anomaly from 200 to $1500 \mathrm{~m}$, which means there was no marked difference between the intermediate water (MIEW) and the deep Mediterranean water (DMW). This agrees with the high degree of homogeneity reported below the intermediate water (Lacombe et al., 1985). Consequently, our 1000 and $1500 \mathrm{~m}$ data will be assume to belong to DMW.

Nutrient profiles (Figure 6) followed the typical variations encountered in the northwestern Mediterranean: very low concentrations in the photic layer, followed by a rapid increase and an almost constant level below $200 \mathrm{~m}$. Concentrations at depths of 1000-1500 $\mathrm{m}$ (nitrate $7.9 \mu \mathrm{mol} \mathrm{l}^{-1}$, phosphate $0.35 \mu \mathrm{mol} \mathrm{l}^{-1}$, silicate $8.4 \mu \mathrm{mol} \mathrm{l}^{-1}$ ) closely agreed with those previously published (McGill, 1965; Karafistan et al., 2002). 

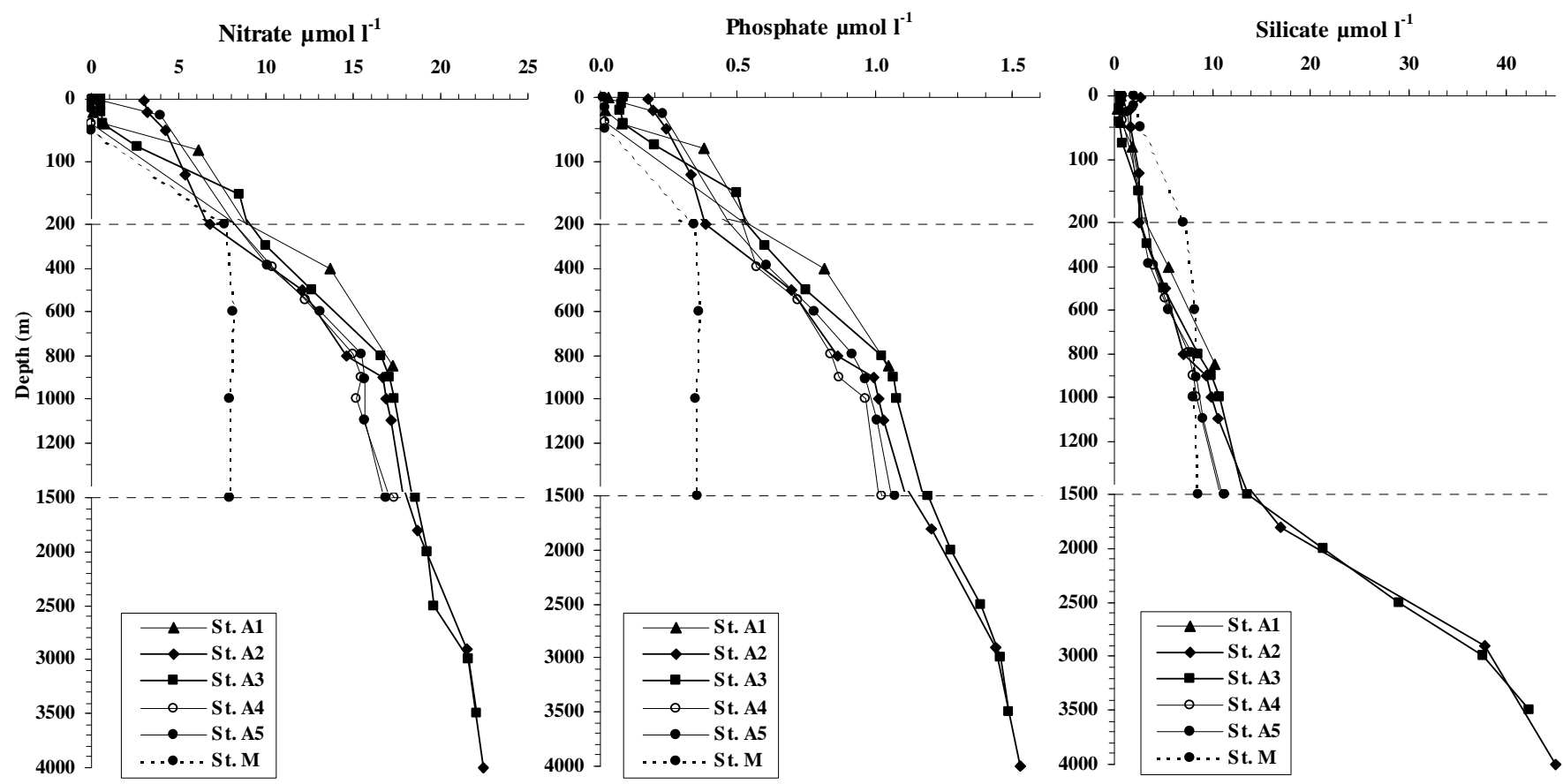

Figure 6. Vertical profiles of nutrients in the N-E Atlantic and in the N-W Mediterranean. Note the different scales as a function of depth. Typical water bodies are indicated in Figure 4.
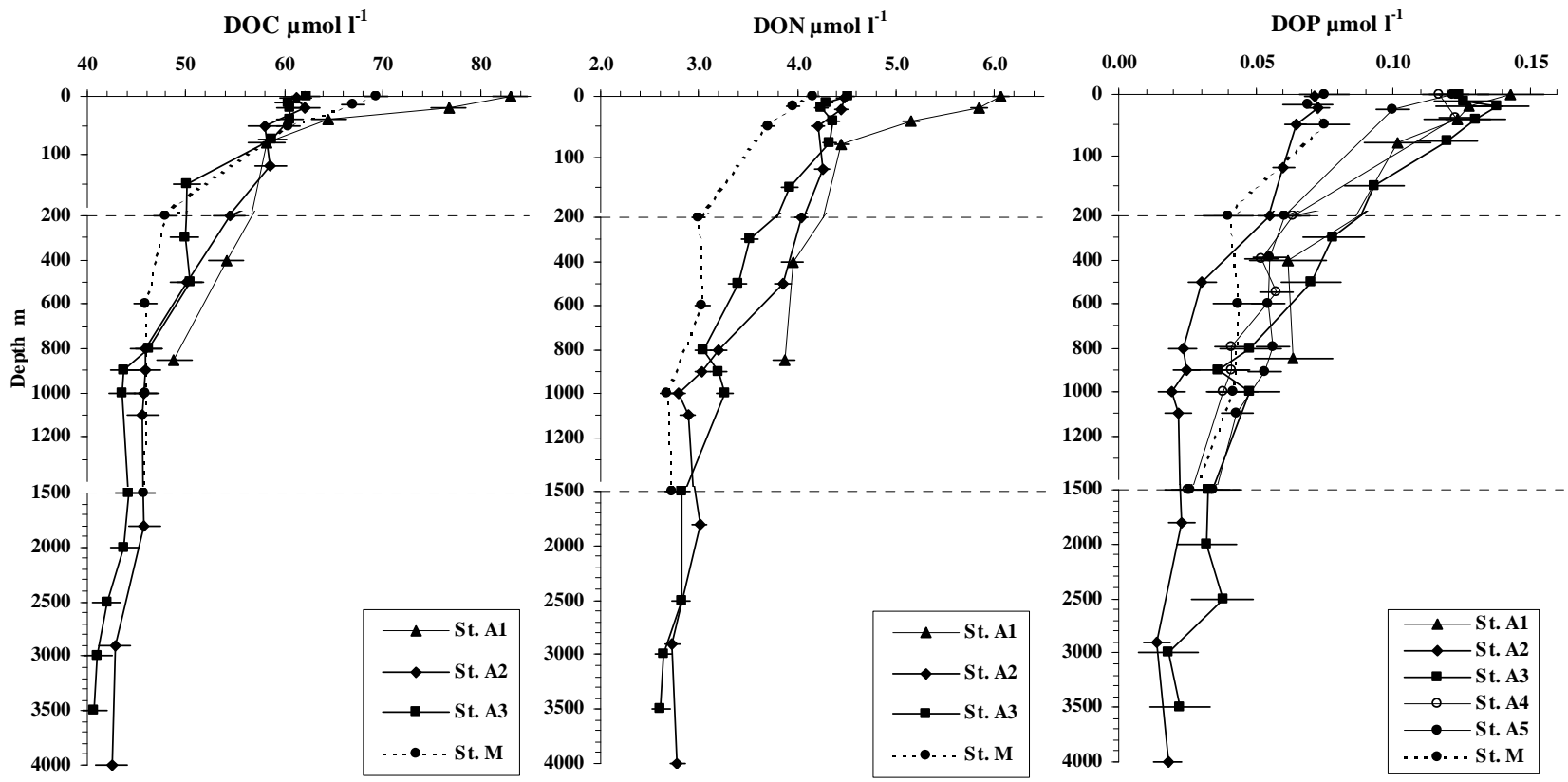

Figure 7. Vertical profiles of DOC, DON and DOP in the N-E Atlantic and in the N-W Mediterranean. Analytical standard deviations are indicated. Note the different scales as a function of depth. Typical water bodies are indicated in Figure 4. 


\subsection{Vertical distribution patterns of DOC, DON and DOP}

Vertical profiles of DOC, DON and DOP concentrations are illustrated in Figure 7 and summarized for the main water masses in Table 3.

Table 3. Summary of DOC, DON and DOP concentration ranges and DOC:DON, DOC:DOP and DON:DOP atomic ratio ranges in the main water masses in the N-E Atlantic (stations A1 to A5) and the N-W Mediterranean (station M). Precision is illustrated in Figures 7 and 8.

\begin{tabular}{|c|c|c|c|c|c|c|c|c|}
\hline Water mass* & Station (date) & $\mathrm{n}^{* *}$ & $\begin{array}{c}\text { DOC } \\
\mu \mathrm{mol} \mathrm{l}^{-1}\end{array}$ & $\begin{array}{c}\text { DON } \\
\mu \mathrm{mol} \mathrm{l}^{-1}\end{array}$ & $\begin{array}{c}\text { DOP } \\
\mu \mathrm{mol} \mathrm{l}^{-1}\end{array}$ & DOC:DON & DOC:DOP & DON:DOP \\
\hline \multirow[t]{6}{*}{ Surface layer } & A1 $(09 / 85)$ & 2 & $77-83$ & $5.8-6.1$ & $0.12-0.14$ & $13.1-13.7$ & $580-600$ & $42-46$ \\
\hline & A2 $(04 / 02)$ & 1 & 61 & 4.5 & 0.07 & 13.7 & 850 & 62 \\
\hline & A3 $(09 / 87)$ & 4 & $61-62$ & $4.2-4.5$ & $0.12-0.14$ & $13.8-14.3$ & $440-500$ & $31-36$ \\
\hline & A4 (07/90) & 1 & - & - & 0.12 & - & - & - \\
\hline & A5 $(07 / 90)$ & 1 & - & - & 0.12 & - & - & - \\
\hline & M (09/84) & 2 & $67-69$ & $4.0-4.2$ & $0.08-0.08$ & $16.7-16.9$ & $920-970$ & $55-57$ \\
\hline \multirow[t]{6}{*}{$200-600 \mathrm{~m}$} & A1 $(09 / 85)$ & 1 & 54 & 4.0 & 0.06 & 13.7 & 880 & 65 \\
\hline & A2 $(04 / 02)$ & 2 & $50-55$ & $3.9-4.1$ & $0.03-0.05$ & $13.0-13.5$ & $1000-1700$ & $74-130$ \\
\hline & A3 $(09 / 87)$ & 2 & $50-51$ & $3.4-3.5$ & $0.07-0.08$ & $14.2-14.8$ & $640-720$ & $45-49$ \\
\hline & A4 (07/90) & 3 & & & $0.05-0.06$ & & & \\
\hline & A5 (07/90) & 3 & & & $0.05-0.06$ & & & \\
\hline & M (09/84) & 2 & $46-48$ & $3.0-3.0$ & $0.04-0.04$ & $15.1-16.0$ & $1100-1200$ & $70-76$ \\
\hline \multirow[t]{6}{*}{$800-1500 \mathrm{~m}$} & A1 $(09 / 85)$ & 1 & 49 & 3.9 & 0.06 & 12.6 & 770 & 61 \\
\hline & A2 $(04 / 02)$ & 4 & $46-46$ & $2.8-3.2$ & $0.02-0.02$ & $14.4-16.4$ & $1900-2400$ & $120-150$ \\
\hline & A3 $(09 / 87)$ & 3 & $44-46$ & $3.1-3.3$ & $0.04-0.05$ & $13.3-15.2$ & $920-1200$ & $64-88$ \\
\hline & A4 (07/90) & 3 & & & $0.04-0.04$ & & & \\
\hline & A5 $(07 / 90)$ & 3 & & & $0.04-0.06$ & & & \\
\hline & M (09/84) & 2 & $46-46$ & $2.7-2.7$ & $0.03-0.04$ & $16.8-17.2$ & $1100-1800$ & 64-106 \\
\hline \multirow[t]{2}{*}{$3000-4000 \mathrm{~m}$} & A2 $(04 / 02)$ & 2 & $42-43$ & $2.7-2.8$ & $0.01-0.02$ & $15.3-15.7$ & $2400-3100$ & $160-200$ \\
\hline & A3 $(09 / 87)$ & 2 & $41-41$ & $2.6-2.6$ & $0.02-0.02$ & $15.5-15.6$ & $1800-2300$ & $120-150$ \\
\hline
\end{tabular}

* Corresponding water masses: Surface layer = above thermocline; 200-600 $\mathrm{m}=$ North Atlantic Central Water (NACW) or Mediterranean Intermediate Eastern Water (MIEW); 800$1500 \mathrm{~m}=$ North Atlantic Mediterranean Water (NAMW; actually, 800-1200 m) or Deep Mediterranean Water (DMW); 3000-4000 m = North Atlantic Deep Water (NADW). $* * \mathrm{n}=$ number of results in a water mass. 
$D O C$

The vertical profiles show the classic surface-to-bottom decrease, i.e., an accumulation in the upper productive layer and progressive downward degradation, along with water mass aging. One essential feature is the marked DOM gradients associated with water mass boundaries such as the upper thermocline and the main pycnocline. In the Atlantic, in open sea, the drop between NASW and NACW was $6 \mu \mathrm{mol}^{-1}(\sim 10 \%)$ in April (st. A2: 61 to 55 $\mu \mathrm{mol} \mathrm{l}^{-1}$ ) and $11 \mu \mathrm{mol} \mathrm{l}^{-1}(\sim 20 \%)$ in September (st. A3: 61-62 to $51 \mu \mathrm{mol} \mathrm{l}^{-1}$ ). At station A1, DOC concentrations were markedly higher, with a surface concentration of $\sim 80 \mu \mathrm{mol} \mathrm{l}^{-1}$ and a drop below the thermocline by $\sim 25 \mu \mathrm{mol}^{-1}(\sim 30 \%)$. In the Mediterranean, DOC dropped by $\sim 20 \mu \mathrm{mol} \mathrm{l}^{-1}(\sim 30 \%)$ from 67-69 $\mu \mathrm{mol} \mathrm{l}^{-1}$ in the upper layer to $48 \mu \mathrm{mol}^{-1}$ in MIEW.

In the Atlantic, the main pycnocline between NACW and NAMW was associated with a significant decrease of 4-5 $\mu \mathrm{mol} \mathrm{l}^{-1}$ DOC in the 500-800 m layer. In the underlying waters (800-1500 m), similar DOC values were measured in open sea in the Atlantic and in the Mediterranean $\left(44-46 \mu \mathrm{mol} \mathrm{l}^{-1}\right)$. These data agree with those previously published for the same areas (Table 4).

Table 4. Main recent literature data for DOC and DON in the area studied compared with the present results.

\begin{tabular}{|c|c|c|c|c|}
\hline Layer or water body & Location & $\begin{array}{c}\text { DOC } \\
\mu \mathrm{mol} \mathrm{l}^{-1}\end{array}$ & $\begin{array}{c}\text { DON } \\
\mu \mathrm{mol} \mathrm{l}^{-1}\end{array}$ & Reference \\
\hline \multicolumn{5}{|c|}{ NORTH-EAST ATLANTIC OCEAN } \\
\hline \multirow[t]{2}{*}{ Surface layer } & West of Scotland & $56-58$ & $3-4$ & Alvarez-Salgado and Miller, 1998 \\
\hline & Bay of Biscay & $61-62$ & $4.2-4.5$ & This study \\
\hline \multirow[t]{3}{*}{ 200-500 m (NACW) } & West of Scotland & $51-52$ & $1.9-2.1$ & Alvarez-Salgado and Miller, 1998 \\
\hline & Bay of Cadiz & $48-49$ & - & Dafner et al., 1999 \\
\hline & Bay of Biscay & $50-54$ & $3.4-4.1$ & This study \\
\hline \multirow[t]{3}{*}{$1000-1500 \mathrm{~m}$} & West of Scotland & $46-48$ & 2.5 & Alvarez-Salgado and Miller, 1998 \\
\hline & N-E Atlantic & $\sim 44$ & - & Kähler and Koeve, 2001 \\
\hline & Bay of Biscay & $43-46$ & $2.8-3.3$ & This study \\
\hline \multicolumn{5}{|c|}{ MEDITERRANEAN SEA Western basin } \\
\hline \multirow[t]{4}{*}{ Surface layer } & North Corsica & $75-85$ & - & Copin-Montégut and Avril, 1993, fig 2 \\
\hline & Off North of Spain & $\sim 65-75$ & $\sim 4-5$ & Doval et al., 1999, fig 4 stations 6-9 \\
\hline & Gulf of Lions & $80-100$ & $4.5-5.5$ & Raimbault et al., 1999 \\
\hline & Off Gulf of Lions & $67-69$ & $4.0-4.2$ & This study \\
\hline \multirow[t]{4}{*}{$1000-1500 \mathrm{~m}$} & North Corsica & $\sim 50-58$ & - & Copin-Montégut and Avril, 1993, fig 2 \\
\hline & Western basin & $45-55$ & - & Cauwet et al., 1997 \\
\hline & Off North of Spain & $\sim 46-51$ & 2.9 & Doval et al., 1999, fig 5 \\
\hline & Off Gulf of Lions & 46 & 2.7 & This study \\
\hline
\end{tabular}

Below $1500 \mathrm{~m}$ in the Atlantic (stations A2 and A3), DOC concentrations decreased regularly at a rate of 1.5-2 $\mu \mathrm{mol} \mathrm{^{-1 }}$ per kilometer to $41-42 \mu \mathrm{mol} \mathrm{l}^{-1}$ at depths $>3500 \mathrm{~m}$. This may be attributed to mixing of NADW with AABW, which contains a lower DOC concentration (Hansell and Carlson, 1998). However, it contrasts with the homogeneity reported by Hansell and Carlson (1998), between 1100 to $4800 \mathrm{~m}$ at $48^{\circ} \mathrm{N}$ (45.1 \pm $0.4 \mu \mathrm{mol} \mathrm{l}^{-1} ; 19$ samples). 
$D O N$

DON profiles mimic those of DOC. Open sea upper layer DON concentrations were within 4.0-4.5 $\mu \mathrm{mol} \mathrm{l}^{-1}$, showing no difference in the Atlantic between station A2 (April 2002) and station A3 (September 1987). Contrary to DOC, DON concentrations in the Mediterranean (station M) tended to be slightly lower than in the Atlantic. The average differences in the top 40-50 m between the two seas $\left(0.2-0.4 \mu \mathrm{mol} \mathrm{l}^{-1} \mathrm{DON}\right)$ were significant.

The DON gradients between the upper layer and the 200-600 m layer were parallel to those observed for DOC. In the Atlantic, DON dropped by $0.5 \mu \mathrm{mol} \mathrm{l}^{-1}$ in April and $0.9 \mu \mathrm{mol} \mathrm{l}^{-1}$ in September, while in the Mediterranean, the drop was greater, $1.1 \mu \mathrm{mol} \mathrm{l}^{-1}$. The continental influence was marked at station A1, with a surface concentration of $\sim 6 \mu \mathrm{mol} \mathrm{l}^{-1}$ followed by a drop of $\sim 2 \mu \mathrm{mol} 1^{-1}$. The relative differences of DON between the upper and the underlying water masses were quite identical to those calculated for DOC, i.e. $\sim 10 \%$ at station $\mathrm{A} 2, \sim 20 \%$ at station $\mathrm{A} 3$ and $\sim 30 \%$ at stations $\mathrm{A} 1$ and $\mathrm{M}$.

In NACW, the DON concentration was significantly higher in April $2002\left(\sim 4 \mu \mathrm{mol} \mathrm{l}^{-1}\right)$ than in September $1987\left(\sim 3.5 \mu \mathrm{mol} \mathrm{l}^{-1}\right)$. Gradients through the main pycnocline between NACW and NAMW were significant, with decreases of 0.4-0.7 $\mu \mathrm{mol}^{-1} \mathrm{DON}$.

Atlantic and Mediterranean DON values were similar at $1500 \mathrm{~m}\left(2.7-2.8 \mu \mathrm{mol}^{-1}\right)$, and in the deepest Atlantic waters (3000-4000 m), DON was in the range 2.6-2.8 $\mu \mathrm{mol} \mathrm{l}^{-1}$.

Although many papers have dealt with methods for the determination of DON, few deep profiles have been published in the areas studied here (Table 4). A wider scattering of DON data can be noted, compared to DOC data.

$D O P$

In the upper layer the Atlantic DOP concentrations showed a marked difference between concentrations at station A2 $\left(\sim 0.07 \mu \mathrm{mol} \mathrm{l}^{-1}\right.$; early spring $)$ and at station A3 (0.12$0.14 \mu \mathrm{mol} \mathrm{l}^{-1}$; early autumn). No marked continental influence could be identified at station A1. Variation in DOP concentrations between the upper layer and underlying (200-600 m) water was lower in spring $\left(\sim 0.02-0.03 \mu \mathrm{mol} \mathrm{l}^{-1}\right)$ than in autumn $\left(0.05-0.08 \mu \mathrm{mol}^{-1} ; 40-50 \%\right.$ of surface concentration). Nevertheless, in the Mediterranean the concentration in the 200-600 $\mathrm{m}$ water layer was consistently about $50 \%$ that of the surface layer.

NACW DOP concentrations measured in 1987-1990 lay in the range 0.05-0.08 $\mu \mathrm{mol}^{-1}$ while the 2002 values were lower by $\sim 0.02-0.03 \mu \mathrm{mol}^{-1}$. Similarly, in the NAMW the average DOP concentration were higher in 1987-1990, i.e., $0.045 \pm 0.007 \mu \mathrm{mol} \mathrm{l}^{-1}(\mathrm{n}=9)$ than in 2002 , i.e. $0.022 \pm 0.002 \mu \mathrm{mol} \mathrm{l}^{-1}(\mathrm{n}=4)$. In contrast, concentrations in deep waters $(\geq 1500 \mathrm{~m}$ ) did not differ significantly with regard to analytical variability (see Figure 7). In the bottom North Atlantic Deep Water (3000-4000 m), DOP was found to be close to $0.02 \mu \mathrm{mol} \mathrm{l}^{-1}$ on average, both in 1987 and 2002.

In the Mediterranean, $\sim 0.04 \mu \mathrm{mol}{ }^{-1}$ DOP was measured in the intermediate water and $\sim 0.03 \mu \mathrm{mol}^{-1}$ in the deep water, i.e., similar to that found in the Atlantic at 1500-2000 m.

Despite the increasing number of DOP measurements in the ocean (Karl and Björkman, 2002), information available for the area investigated remains scarce. In surface water, 0.04 to $0.14 \mu \mathrm{mol} \mathrm{l}^{-1}$ DOP were measured in the North Atlantic (Ridal and Moore, 1990; Wu et al., 2000) and 0.06-0.10 $\mu \mathrm{mol} \mathrm{l}^{-1}$ DOP in the N W Mediterranean (Raimbault et al., 1999). In deep waters, Ridal and Moore $(1990,1992)$ found $<0.05 \mu \mathrm{mol} \mathrm{l}^{-1}$ in the North Atlantic and Pacific, while Raimbault et al. (1999) reported undetectable levels below $200 \mathrm{~m}$ in the Mediterranean.

\subsection{Vertical distribution patterns of DOM elemental ratios $C: N, C: P$ and $N: P$}

Elemental ratios for DOM within a water sample are expressed as $\mathrm{C}: \mathrm{N}: \mathrm{P}$ or $\mathrm{C}: \mathrm{N}, \mathrm{C}: \mathrm{P}$ and N:P. The corresponding profiles are shown in Figure 8 and Table 3. 

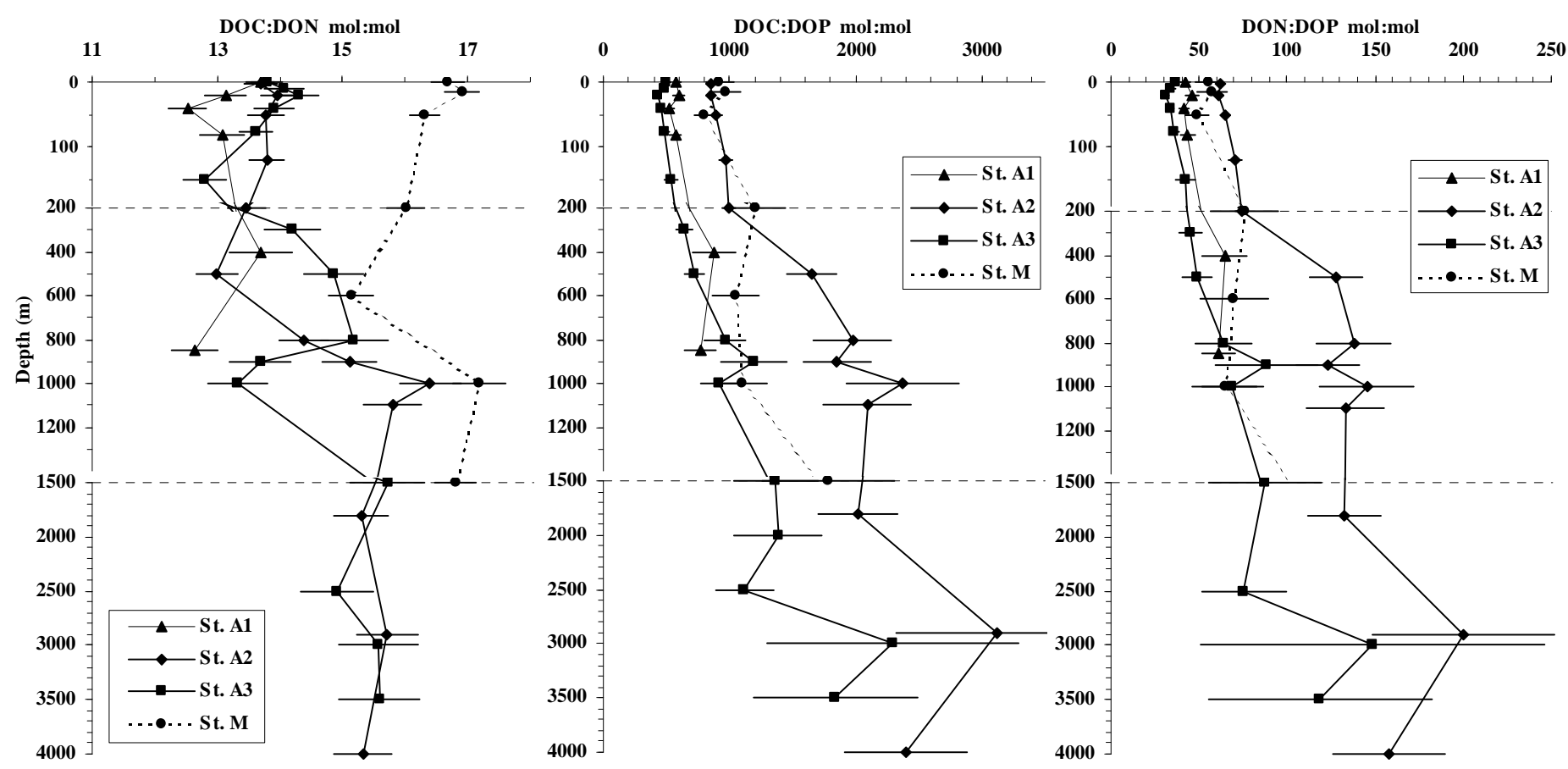

Figure 8. Vertical profiles of DOC:DON, DOC:DOP and DON:DOP atomic ratios in the N-E Atlantic and in the N-W Mediterranean. Standard deviations are indicated. Note the different scales as a function of depth. Typical water bodies are indicated in Figure 4.

\section{DOM C:N ratio}

Higher C:N ratios were measured in the deep Atlantic water $(1500-4000 \mathrm{~m}, \mathrm{C}: \mathrm{N}=15.4$ $\pm 0.3, \mathrm{n}=7)$ than in the surface layer $(\mathrm{C}: \mathrm{N}=13.8 \pm 0.4, \mathrm{n}=7)$. In the Mediterranean, the C:N ratios were higher than in the Atlantic $(\sim 15-17)$ and did not show the same tendency to increase with depth.

The C:N ratio exhibited a minimum below the upper layer in early autumn in the Atlantic (st. A1 and st. A3). Another C:N minimum appeared in the NAMW layer in early autumn 1987 (st. A3, 900 and $1000 \mathrm{~m}$ ). As the two levels showed consistent C:N ratios, the probability of a sampling or analytical artifact is low. However, since such a minimum was not found in April 2002, no simple hypothesis can be suggested for the time being.

DOM C:P ratio

$\mathrm{C}: \mathrm{P}$ ratios increased by a factor of about 3 from surface to deep waters as a consequence of the more drastic decrease in DOP compared to that of DOC. The average C:P values in the 1500-4000 m water (all stations) was: $1900 \pm 600(\mathrm{n}=9)$. In the Atlantic, upper layer C:P ratios were higher in April $(\sim 850)$ than in early autumn $(\sim 450-600$; highest values at st. A1). Early autumn values in the upper layers $(0-200 \mathrm{~m})$ also showed that the C:P ratios, like the $\mathrm{C}: \mathrm{N}$ ratios, were significantly higher in the Mediterranean (900-950) than in the Atlantic.

In contrast with $C: N$ ratios, $C: P$ ratios showed no minima just below the thermocline.

In the intermediate water masses (NACW and NAMW), C:P ratios were higher in April 2002 than in September 1987, essentially due to the lower DOP concentrations.

DOM N:P ratio

Vertical N:P variations closely resembled those of $\mathrm{C}: \mathrm{P}$, as a result of almost similar variations of $\mathrm{C}$ and $\mathrm{N}$ (10\% variation of the $\mathrm{C}: \mathrm{N}$ ratio versus a factor of 3 for the $\mathrm{C}: \mathrm{P}$ ratio). The average N:P value in the 1500-4000 m waters from all stations was $130 \pm 40(n=8)$.

In the Atlantic, upper layer N:P ratios in early autumn were in the $\sim 30-45$ range (highest values at st. A1), while they reached $\sim 60-70$ in April. In early autumn N:P ratios in 
the upper layers (0-200 m) were also significantly higher in the Mediterranean (50-75) than in the Atlantic in open sea (station A3).

Although the range of our N:P values is similar to that of Vidal et al. (1999) in the central Atlantic Ocean, the decreasing downward trend they found contrasts with our results.

\subsection{Relationships of DOC, DON and DOP}

The $\mathrm{x}$ - and $\mathrm{y}$-axes variables of the relationships of DOC, DON and DOP throughout the water column were selected so that slopes could be easily compared with the C:N:P ratios (Figure 9). The linear regression slopes computed from these relationships reflect alteration of DOM due to relative variations in composition. These will be expressed as $\triangle \mathrm{DOC}: \triangle \mathrm{DON}: \triangle \mathrm{DOP}$ (the composition itself being $\mathrm{C}: \mathrm{N}: \mathrm{P}$ ).

The relationships show systematic differences between the upper layers and the underlying waters. Processing in two domains, though it may simplify relationships, gave a satisfactory description of DOM element behavior. The upper domain was found to lie from the surface to the base of the thermocline (or of the winter mixed $500 \mathrm{~m}$ layer at station A2) and the hereafter so-called 'deep' domain below this depth. This difference between the two domains was especially marked in the Mediterranean, as well as at the Atlantic station A1. While DOM in the upper domain was typical of each station, all the deep waters at the open sea stations (A2, A3 and M) could be described by a single regression. Because error is associated with components on both axes, model II linear regressions were used.

The main qualitative features are that DOM is richer in nitrogen at the coastal station $\mathrm{A} 1$ and richer in carbon at station $\mathrm{M}$ than at open sea stations A2 and A3. DOM is also well characterized by its phosphorus content. At stations A1 and M, DOP varied within a restricted range, in contrast with DOC and DON. Between stations A2 (April) and A3 (September), the shift is clearly due to DOP. Straight lines on Figure 9 identify the upper and deep domains. Their slopes are summarized in Table 5.

Table 5. Main parameters of the relationships between DOC, DON and DOP. Data have been omitted when the correlation coefficients were too low.

\begin{tabular}{|c|c|c|c|c|c|c|}
\hline \multirow[b]{2}{*}{ Layer } & \multirow[b]{2}{*}{ Station } & \multirow[b]{2}{*}{$\begin{array}{c}\text { Depth } \\
\mathrm{m}\end{array}$} & \multirow[b]{2}{*}{$\begin{array}{l}\text { Nb. } \\
\text { obs. }\end{array}$} & \multicolumn{3}{|c|}{$\begin{array}{l}\text { Slope } \pm \text { standard error } \\
\left(\mathrm{R}^{2} ; \text { confidence level }\right)\end{array}$} \\
\hline & & & & $\triangle \mathrm{DOC}: \triangle \mathrm{DON}$ & $\Delta \mathrm{DOC}: \triangle \mathrm{DOP}$ & $\Delta \mathrm{DON}: \triangle \mathrm{DOP}$ \\
\hline \multirow[t]{4}{*}{ Upper layer } & A1 & $0-40$ & 3 & $\begin{array}{c}19.8 \pm 2.1 \\
(0.99 ; p<0.01)\end{array}$ & $\begin{array}{c}920 \pm 450 \\
(0.76 ; p=0.1)\end{array}$ & $\begin{array}{c}47 \pm 27 \\
(0.66 ; p=0.2)\end{array}$ \\
\hline & $\mathrm{A} 2$ & $0-500$ & 6 & $\begin{array}{c}19.2 \pm 1.5 \\
(0.98 ; p<0.01)\end{array}$ & $\begin{array}{c}284 \pm 34 \\
(0.94 ; p<0.01)\end{array}$ & $\begin{array}{c}14.8 \pm 2.4 \\
(0.90 ; p<0.01)\end{array}$ \\
\hline & A3 & $0-150$ & 6 & $\begin{array}{c}22.3 \pm 4.1 \\
(0.87 ; p<0.01)\end{array}$ & $\begin{array}{c}282 \pm 58 \\
(0.83 ; p=0.01)\end{array}$ & $\begin{array}{c}12.7 \pm 4.4 \\
(0.51 ; p=0.1)\end{array}$ \\
\hline & M & $0-50$ & 3 & $\begin{array}{c}20.2 \pm 3.7 \\
(0.97 ; p=0.02)\end{array}$ & - & - \\
\hline Deep layer & $\mathrm{A} 2+\mathrm{A} 3+\mathrm{M}$ & $*$ & 20 & $\begin{array}{c}10.0 \pm 1.7 \\
(0.47 ; p<0.01)\end{array}$ & $\begin{array}{c}153 \pm 26 \\
(0.46 ; p<0.01)\end{array}$ & $\begin{array}{c}15.3 \pm 2.5 \\
(0.57 ; p<0.01)\end{array}$ \\
\hline
\end{tabular}

* Below upper layer for each station. 

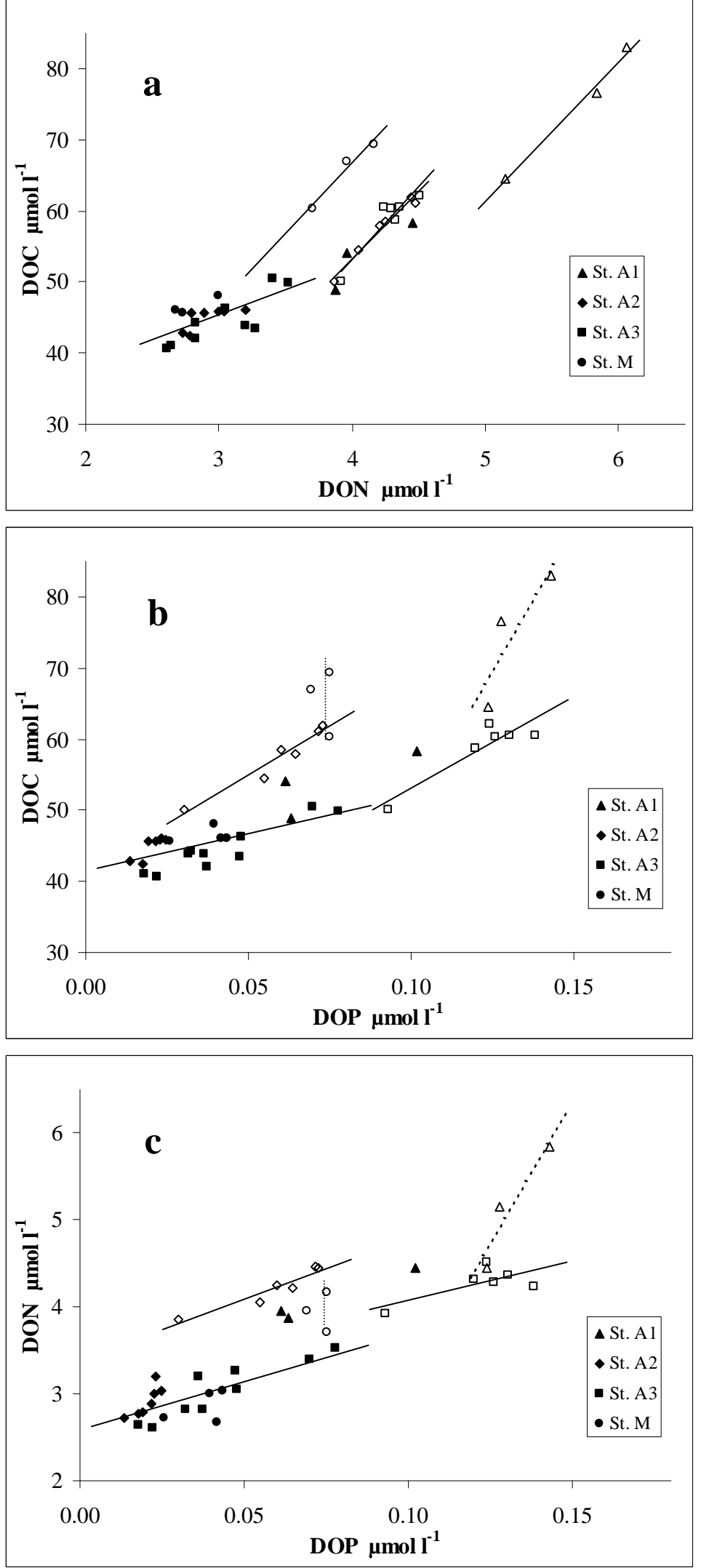

Figure 9. Relationships of a) DOC vs DON, b) DOC vs DOP, c) DON vs DOP in the N-E Atlantic and the N-W Mediterranean. Empty symbols denote the upper layer (from surface to the base of the thermocline). Continuous lines: linear regressions; broken lines: visual data marker. 
In the upper layers, the slopes of DOC vs DON relationships lay in a narrow range of $\triangle \mathrm{DOC}: \triangle \mathrm{DON} \sim 19 \pm 2$ to $22 \pm 4$ and differed significantly from those found in deeper waters $(10.0 \pm 1.7)$. For DOC vs DOP, a comparable difference was found at open sea stations in the Atlantic, between the upper layer $(\triangle \mathrm{DOC}: \triangle \mathrm{DOP} \sim 280 \pm 60$ and $280 \pm 30)$ and deep waters $(\sim$ $153 \pm 26)$. The relationships of DON vs DOP show that upper layer values of stations $A 1$ and $\mathrm{M}$ deviated from an average behavior characterized by $\triangle \mathrm{DON}: \Delta \mathrm{DOP}$ of $\sim 13 \pm 4$ to $15 \pm 2$ either in the upper or the deep layers.

Hopkinson et al. (1997) determined the overall slopes of the relationships between DOC, DON and DOP in the Georges Bank region, from surface to $1500 \mathrm{~m}$, and obtained values that differed from ours, i.e., $\triangle \mathrm{DOC}: \triangle \mathrm{DON} \sim 10, \triangle \mathrm{DOC}: \triangle \mathrm{DOP} \sim 385$ and $\triangle \mathrm{DON}: \triangle \mathrm{DOP} \sim 27$. In the Drake Passage (Antartica) Sanders and Jickells (2000) measured $\Delta \mathrm{TON}: \Delta \mathrm{TOP}=15.7 \pm 1.7$ and $13.8 \pm 1.0$ for two different data sets, which is close to our $\triangle \mathrm{DON}: \triangle \mathrm{DOP}$ values.

\section{DISCUSSION}

\subsection{DOM concentrations in the $\mathrm{N}-\mathrm{E}$ Atlantic}

Open sea stations in the N-E Atlantic were sampled at different times of the year and up to fifteen years apart for A2 and A3. Differences in DOC, DON and DOP concentrations may result from seasonal or long term changes. These were marked for DOP in various water masses, but also significant for DON in NACW.

Due to biological activity (planktonic exudation, dissolution from detritus, bacterial decomposition), concentrations of DOM may vary in surface waters. However, studies of annual variations of DOC showed that maximum concentrations are invariably found in autumn within relative variations of 5-10 \% (Copin-Montégut and Avril, 1993; Hydes et al., 2001; Carlson et al., 1994). Our samples characterized the beginning (st. A2, April 2002), the middle (st. A4 and A5, July 1990) and the end (st. A3, September 1987) of the productive season. In order to compare DOM in the resulting various stratification conditions, DOC, DON and DOP were integrated over the upper $500 \mathrm{~m}$ layer (Table 6), which is the thickness of the upper mixed layer in winter (see Figure 5) and the depth where the main characteristics (temperature, salinity and nutrients concentrations) are quite similar at any time.

Table 6. Integrated DOC, DON and DOP pool in the upper $500 \mathrm{~m}$ layer of open sea stations in the N-E Atlantic.

\begin{tabular}{|c|c|c|c|}
\hline \multirow[t]{2}{*}{ Station (date) } & \multicolumn{3}{|c|}{$\begin{array}{c}\text { 0-500 } \mathrm{m} \text { integrated pool } \\
\mathrm{mmol} \mathrm{m}^{-2}\end{array}$} \\
\hline & DOC & DON & DOP \\
\hline A2 $(04 / 02)$ & 27329 & 2034 & 25.2 \\
\hline A3 $(09 / 87)$ & 26144 & 1884 & 45.2 \\
\hline A4 (07/90) & - & - & 36.4 \\
\hline A5 $(07 / 90)$ & - & - & 33.6 \\
\hline
\end{tabular}

Unexpectedly, the integrated DOC and DON pools were slightly larger (4-7\%) in April than in September. Although the difference is small, it is unlikely to be attributed to 
simultaneous analytical biases in DOC and DON. The trend seems large enough to suggest a low-frequency increase of the DOM pool between 1987 and 2002. North Atlantic climatic oscillations are known to generate temperature changes in the upper water masses. Sampling in 1987 corresponded to the end of a period of low temperatures for the northern European surface water. Subsequently, systematically higher temperatures were recorded (Rodwell et al., 1999; OSPAR Commission, 2000). Beaugrand et al. (2002) showed that climatic changes have induced strong biogeographical shifts in all copepod assemblages in the eastern North Atlantic Ocean. We postulate from our results that the overall production of organic matter in the North Atlantic could have been affected by this climatic event.

The DOP pool variations, which are reported to be relatively greater than those of DOC and DON, are consistent with the progressive increase in DOP from spring to autumn.

Assuming that the $20 \mathrm{mmol} \mathrm{m}^{-2}$ difference in the DOP pool between st. A2 and st. A3 resulted mostly from spring-summer primary production, the equivalent carbon amount was $\sim 2 \mathrm{~mol} \mathrm{~m}^{-2}$ (applying the Redfield ratio C:P $=106: 1$ ). A yearly carbon production of $\sim 4.5$ $5 \mathrm{~mol} \mathrm{~m}^{-2}$ for the North Atlantic (Millero, 1996) together with a net DOP accumulation rate of 10-40 \% (turnover time of 60-300 days; Björkman et al., 2000), would lead to accumulations ranging from 4 to $19 \mathrm{mmol} \mathrm{m}^{-2}$ DOP. Long-term variations of the DOP pool in the $0-100 \mathrm{~m}$ layer (up to $10 \mathrm{mmol} \mathrm{m}$ over two years) have been attributed to changes in microplankton communities, a decrease in the DOP pool resulting from a shift from $\mathrm{N}$ - to P-limitation conditions (Karl and Tien, 1997; Karl and Björkman, 2002). In the present case, while lowfrequency oscillations may be involved in the observed changes in the N-E Atlantic, the seasonal component seemed predominant in the difference observed in DOP pools between early autumn in 1987 and early spring in 2002. Integrated values also confirm that lower April concentrations did not result only from winter mixing with deeper DOP-poor waters, but were mainly a consequence of mineralization.

Station A1, only $35 \mathrm{~km}$ off the coast in the Bay of Biscay, offered a typical example of continental influence. Salinity in the upper layer (34.5-34.9) indicates 2-3\% fresh water. Excess surface DOC and DON with regard to offshore values (respectively about 20 and 1.5 $\mu \mathrm{mol} \mathrm{l}^{-1}$ ) showed a marked (exogenic or endogenic) influence of continental inputs. DOP showed a particular behavior, i.e., there was no excess and an almost constant concentration in the upper $40 \mathrm{~m}$ layer. At that period, the inorganic $\mathrm{N}: \mathrm{P}$ ratio of the main continental input to this area, the French river Adour, was 50-60 (French Government data published in the Water Quality directory), i.e., about 3-4 times the Redfield ratio. Additional concentrations of inorganic nitrogen and phosphorus from fresh water in the surface layer were estimated to be about 3.5 and $0.06 \mu \mathrm{mol} \mathrm{l}^{-1}$ respectively, however, at the sampling time, the total inorganic pools were almost depleted $\left(\mathrm{N} \sim 0.02-0.05 ; \mathrm{P} \sim 0.02-0.03 \mu \mathrm{mol}^{-1}\right)$. To consume excess DIN, phytoplancton had to recycle P from DOM (Cotner et al., 1997; Karl and Björkman, 2002), which prevented accumulation of DOP (in contrast with DOC and DON). In addition, Plimitation in the south of the Bay of Biscay has recently been confirmed (Labry et al., 2002).

\subsection{Comparison of Mediterranean and Atlantic open sea DOM}

Our results point out that deep water (1500 m depth) DOC, DON and DOP concentrations were similar within analytical uncertainty in the N-E Atlantic and in the N-W Mediterranean. In contrast, concentrations in the open sea upper layer (top 40-50 m) indicate analytically significant differences. While DOC was higher in the Mediterranean than in the Atlantic (resp.67-69 and 60-62 $\mu \mathrm{mol}^{-1}$ ), the opposite was observed for DON (resp. 3.96-4.06 and 4.24-4.51 $\mu \mathrm{mol} \mathrm{l}^{-1}$ ) and DOP (resp. 0.07-0.08 and 0.12-0.14 $\mu \mathrm{mol} \mathrm{l}^{-1}$ ). Concentrations at station $\mathrm{M}$ were confirmed by comparable values measured around Corsica $(\mathrm{N}-\mathrm{W}$ Mediterranean) during the same cruise (DOC: 68-74 $\mu \mathrm{mol} \mathrm{l}^{-1}$; DON: 4.1-4.3 $\mu \mathrm{mol} \mathrm{l}^{-1}$; DOP : 0.06-0.07 $\mu \mathrm{mol} \mathrm{l}^{-1}$; unpublished). Since maximum DOC concentrations are invariably found 
in autumn in the N-W Mediterranean and in the N-E Atlantic (Copin-Montégut and Avril, 1993; Hydes et al., 2001) valid comparison can be made of the two areas. The difference between Mediterranean and Atlantic surface waters is illustrated by the relationships between DOC, DON and DOP (Figure 9). Results from other authors tend to confirm this difference. Over an annual cycle, Copin-Montégut and Avril (1993) reported 75-85 $\mu \mathrm{mol}^{-1}$ DOC northwest of Corsica, while Carlson et al. (1994) measured 62-70 $\mu \mathrm{mol} \mathrm{l}^{-1}$ in the Sargasso Sea. Unfortunately, values reported by Ferrari (2000) in the vicinity of our stations (Bay of Biscay: 75-187 $\mu \mathrm{mol} \mathrm{l}^{-1}$; N-W Mediterranean: 112-141 $\mu \mathrm{mol} \mathrm{l}^{-1}$ ) can be questioned.

As a consequence of these differences, DOM was characterized by higher $\mathrm{C}: \mathrm{N}$ and $\mathrm{C}: \mathrm{P}$ ratios in the upper layer in the Mediterranean (resp. 17 and 950) than in the Atlantic (resp. $\sim 14$ and $\sim 450$ ). High C:N ratios of $15.5 \pm 0.4$ were also measured by Doval et al. (1999) in the N-W Mediterranean (Balearic islands), for the whole water column, with ratios exceeding 16 far from the coast. Our results indicate that, in the Mediterranean surface layer, DOM was much poorer in $\mathrm{N}$ by about $20 \%$ and in $\mathrm{P}$ by about $50 \%$ than in the Atlantic.

The surface water of the western Mediterranean basin results from the spreading of the North Atlantic Surface Water which enters through the strait of Gibraltar. This water moves east- and northeastward according to the general cyclonic surface circulation in the western Mediterranean basin (Lacombe and Tchernia, 1972). If concentrations in water entering the Mediterranean were correctly reflected by our NASW DOM results from the Bay of Biscay, this implies that waters of the N-W Mediterranean were enriched in DOC and impoverished in DON and DOP during their transport. DOC enrichment could be attributed to atmospheric inputs, a process which has been shown to play a major role in the biogeochemistry of the Mediterranean (Martin et al., 1989). However, the simultaneous depletion in DON and DOP implies more consumption or mineralization than production. The $\mathrm{N}-\mathrm{W}$ Mediterranean is described as an oligotrophic system where phosphorus plays a major role in the limitation of primary production (Berland et al., 1980). Consequently, phytoplankton may need to hydrolyze DOP to grow under low-phosphate conditions (Cotner et al., 1997; Karl and Björkman, 2002), thus maintaining low DOP concentrations. DOM characteristics can also result from the process of carbon overconsumption (i.e., the consumption of inorganic carbon compared to inorganic nitrogen exceeding the Redfield ratio; Williams, 1995). This process, which generates a summer accumulation of DOM with a high $\mathrm{C}: \mathrm{N}$ ratio in surface waters, particularly in oligotrophic systems (Sambrotto et al., 1993; Kähler and Koeve, 2001; Körtzinger et al., 2001), is liable to occur in the Mediterranean.

\subsection{Refractory and labile DOM}

Primary production, occurring in the upper photic layer via photosynthetic algae, is the main source of organic matter in the oceans. DOM results from various known mechanisms such as exudation of phytoplankton, excretion, cell lysis, breakdown and dissolution of particles, and bacterial activity (Riley and Chester, 1971). It has been generally accepted that DOM could be regarded as being composed of two major pools. One is recent and labile, resulting from biological excretion and partial bacterial mineralization, while the second is older and refractory (Pomeroy, 1974; Menzel, 1974; Ogura, 1975; Bada and Lee, 1977). In a more detailed approach the bulk pool is divided into three fractions with quite different turnover times: very labile (hours/days), semi-labile (months/seasons) and refractory (hundreds to thousands of years) pools (Kirchman et al., 1993; Carlson and Ducklow, 1995). While differentiation between the labile and semi-labile pools requires specific kinetic studies, it is simple to estimate the two major pools (labile+semi-labile and refractory). Based on the assumption that the refractory pool measured in deep waters $(\geq 1500 \mathrm{~m})$ is homogeneously distributed throughout the water column (Carlson and Ducklow, 1995), the excess of DOC, 
DON and DOP in the photic layer with respect to the refractory DOM (rDOM) represents the labile+semi-labile DOM (also called non-refractory DOM or nrDOM, hereafter).

In the present study, the decrease of DOM concentrations in 2000-4000 m waters was attributed to mixing of water bodies of different ages. Therefore, the data from 1500-2000 m were considered to be the valid values of refractory DOC, DON and DOP for the subsequent determination of the non-refractory fractions in the overlaying waters. Assuming that rDOM is homogeneous over an oceanic basin, refractory concentrations were obtained by averaging all the 1500-2000 m results, Mediterranean rDOM being considered as from Atlantic origin (the results were not significantly different; Figure 6). Concentrations and element ratios of rDOM are summarized in Table 7. Average C:N:P ratios of 1570:100:1 were found in the refractory DOM. This $\mathrm{C}: \mathrm{N}$ ratio of $15.7 \mathrm{in} \mathrm{CDOM}$ is well within the range of values measured in the deep ocean, i.e., 13-18 with few exceptions (Bronk, 2002).

Table 7. Average characteristics of the refractory DOM found at depths of $1500-2000 \mathrm{~m}$ in the N-E Atlantic and in the M-W Mediterranean. Standard deviations are derived from total variance due to analysis and averaging.

\begin{tabular}{lcccccc}
\hline Parameter & $\begin{array}{c}\text { rDOC } \\
\mu \mathrm{mol} \mathrm{l}^{-1}\end{array}$ & $\begin{array}{c}\text { rDON } \\
\mu \mathrm{mol} \mathrm{l}^{-1}\end{array}$ & $\begin{array}{c}\text { rDOP } \\
\mu \mathrm{mol} \mathrm{l}^{-1}\end{array}$ & $\begin{array}{c}\text { rDOC: } \\
\text { rDON }\end{array}$ & $\begin{array}{c}\text { rDOC: } \\
\text { rDOP }\end{array}$ & $\begin{array}{c}\text { rDON: } \\
\text { rDOP }\end{array}$ \\
\hline Nb. of obs. & 4 & 3 & 6 & - & - & - \\
Range & $43.8-45.8$ & $2.73-3.00$ & $0.023-0.034$ & - & - & - \\
Average & 44.9 & 2.85 & 0.029 & 15.7 & 1570 & 100 \\
Std. dev. & 1.7 & 0.17 & 0.009 & 0.6 & 230 & 16 \\
\hline
\end{tabular}

The characteristics of the non-refractory DOM in the surface layer were obtained by subtracting rDOM from DOM (Table 8). They were determined only for the layer above the thermocline, which is the oceanic area where most of the DOM is produced before being injected in the water column. At the periods of study (early spring or early autumn) nrDOM approximated semi-labile DOM since other investigators have found labile DOM (turnover times of hours to days) to be undetectable when phytoplankton activity was low (Carlson and Ducklow, 1995). Station A1 was disregarded because of the unknown, but significant contribution of terrestrial DOM in the surface layer.

In the open sea upper layer, the proportions of nrDOM with regard to total DOM were approximately 25-35\% for DOC, 30-35\% for DON, and 60-80 \% for DOP. In the Atlantic, relative contributions of nrDOM to DOM were on the order of \%nrDOC $<\%$ nrDON $<$ $\%$ nrDOP. The stoichiometry shows that non-refractory DOM was richer in $\mathrm{N}$ by $\sim 30 \%$ and in $\mathrm{P}$ by a factor of 4 to 10 , compared with refractory DOM. In the Mediterranean \%nrDOC was greater than $\%$ nrDON, but $95 \%$ confidence intervals overlap, preventing a clear conclusion. Nevertheless, our figures compare well with measurements taken in the integrated upper $50 \mathrm{~m}$ of the Mediterranean in June by Doval et al. (1999), i.e., nrDOM amounting to $32 \%$ for DOC (in this study: $34 \%$ ) and $33 \%$ for DON (in this study: $30 \%$ ). According to these authors, similar proportions of nrDOC were found in other oligotrophic areas.

$\mathrm{C}: \mathrm{N}: \mathrm{P}$ ratios of 380:38:1, 159:15:1 and 530:28:1 were found at stations A2, A3 and $\mathrm{M}$ respectively. Elemental ratios of the non-refractory DOM were much lower than those of refractory DOM, except for C:N in the Mediterranean. The element ratios show that the nonrefractory DOM in the Mediterranean differed from that found in the Atlantic since it was just three times richer in $\mathrm{P}$ than the refractory fraction but $20 \%$ poorer in $\mathrm{N}$. This contrasts with 
the results of Doval et al. (1999) who found a slightly lower C:N ratio in the non-refractory DOM pool of the upper $50 \mathrm{~m}$ compared with the refractory pool.

Table 8. Characteristics of the non-refractory (labile + semi-labile) pool of DOM in the surface layer (above thermocline; number of samples mentioned in Table 3) in the N-E Atlantic (st. A2 to A5) and in the N-W Mediterranean (st. M). Value \pm standard deviation. The standard deviations are derived from the sum of variances of DOM and rDOM components (including analysis and averaging contributions). In parentheses: percent of total DOM element.

\begin{tabular}{ccccccc}
\hline Station (date) & $\begin{array}{c}\text { nrDOC } \\
\mu \mathrm{mol}^{-1}\end{array}$ & $\begin{array}{c}\text { nrDON } \\
\mu \mathrm{mol}^{-1}\end{array}$ & $\begin{array}{c}\text { nrDOP } \\
\mu \mathrm{mol} \mathrm{l}^{-1}\end{array}$ & $\begin{array}{c}\text { nrDOC: } \\
\text { nrDON }\end{array}$ & $\begin{array}{c}\text { nrDOC: } \\
\text { nrDOP }\end{array}$ & $\begin{array}{c}\text { nrDON: } \\
\text { nrDOP }\end{array}$ \\
\hline A2 (04/02) & $16.3 \pm 2.4$ & $1.6 \pm 0.2$ & $0.04 \pm 0.01$ & $10.1 \pm 1.4$ & $380 \pm 70$ & $38 \pm 7$ \\
& $(27 \pm 4 \%)$ & $(36 \pm 4 \%)$ & $(60 \pm 14 \%)$ & & & \\
A3 (09/87) & $16.0 \pm 2.4$ & $1.5 \pm 0.2$ & $0.10 \pm 0.02$ & $10.7 \pm 1.2$ & $159 \pm 16$ & $14.8 \pm 1.6$ \\
& $(26 \pm 4 \%)$ & $(34 \pm 5 \%)$ & $(78 \pm 12 \%)$ & & & - \\
A4 (07/90) & - & - & $0.09 \pm 0.01$ & - & - & - \\
A5 (07/90) & - & - & $0.09 \pm 0.01$ & - & & \\
& & & & $(76 \pm 11 \%)$ & & \\
M (09/84) & $23.3 \pm 2.7$ & $1.2 \pm 0.2$ & $0.04 \pm 0.01$ & $19.2 \pm 2.7$ & $530 \pm 100$ & $28 \pm 6$ \\
& $(34 \pm 4 \%)$ & $(30 \pm 6 \%)$ & $(60 \pm 19 \%)$ & & & \\
\hline
\end{tabular}

$\mathrm{C}: \mathrm{N}$ ratios close to the Redfield value of 6.6 (Redfield et al., 1963), can be expected for particulate organic matter issued from primary production and exported toward deeper waters (e.g., Hobson and Menzel, 1969; Doval et al., 1999; Körtzinger et al., 2001). On the contrary, for freshly produced DOM, no single relation between DOC and DON can be found (Kähler and Koeve, 2001). While exudation and excretion of nitrogen-rich compounds like urea $(\mathrm{C}: \mathrm{N}=0.5)$ or proteins and amino acids $(\mathrm{C}: \mathrm{N} \sim 4)$ by microplankton and zooplankton are well documented (e.g., Webb and Johannes, 1967; Schell, 1974; Nagata and Kirchman, 1991), other studies have shown that nitrogen-poor, even nitrogen-free molecules, like carbohydrates and polysaccharides, are also released (Myklestad and Haug, 1972; Myklestad et al., 1989; Staats et al., 2000). Proportions of nitrogen-rich or nitrogen-poor DOM are likely to depend on many factors and are highly unpredictable.

Comparison of nrDOM stoichiometry with the Redfield C:N:P ratios (106:16:1) shows that the $C: \mathrm{N}$ ratios in the Atlantic surface layer were about 1.5 times the Redfield value, while $\mathrm{C}: \mathrm{P}$ ranged from 1.5-fold (September) to 3-fold (April). At the end of the productive season, the N:P ratio of DOM (14.8) was close to the Redfield ratio. In comparison, accumulated nrDOM in the Mediterranean was almost two times poorer in $\mathrm{N}$ than in the Atlantic $(\mathrm{C}: \mathrm{N}=19$ compared to 11), and 3 times poorer in $\mathrm{P}(\mathrm{C}: \mathrm{P}=530$ compared to 160). The stoichiometry of the non-refractory DOM in the Mediterranean suggests that carbon overconsumption (responsible for $\mathrm{N}$ - and P-poor DOM) induced by oligotrophy (enhancing DON and DOP recycling) could be a main process in that sea.

Because of the low amounts of nrDOM remaining below the thermocline, its characteristics could not be determined with precision. Nevertheless, taking DOC as the most reliable proxy for DOM, we calculated that $31 \%$ of nrDOC was found in September below the base of the thermocline in the Atlantic but only $13 \%$ in the Mediterranean, although 
higher concentrations of nrDOM were measured in the upper layer in the latter area. This suggests that DOM is more actively recycled in the Mediterranean.

\subsection{Stoichiometry of DOM dynamics}

DOM produced in the surface layer is transferred to the whole water column by water mass transport, advection and diffusion. During these processes, $\mathrm{C}, \mathrm{N}$ and $\mathrm{P}$ atoms are progressively eliminated from DOM by abiotic and biotic processes. Considering DOC as a satisfactory proxy for DOM, the relationships between DOC, DON and DOP (Figure 9) illustrate how DON and DOP vary as a function of the concentration of DOM. There is a general consensus that DON and DOP are selectively mineralized with respect to DOC (Ridal and Moore, 1992; Hopkinson et al., 1997; Clark et al., 1998; Loh and Bauer, 2000; Clark Kolowith et al., 2001). This concept results from observations that $\mathrm{C}: \mathrm{N}: \mathrm{P}$ ratios of DOM increase in aged DOM, i.e., as a function of depth, and that residual concentrations of DOP are very low in deep waters. However, this referred to DOM as a whole, whereas the stoichiometry of the refractory and the degradable fractions of DOM are very different. If the stoichiometry were stable for each fraction, the apparent selective removal of $\mathrm{N}$ and $\mathrm{P}$ from the total pool of DOM could simply result from the decreasing proportion of the semi-labile pool from surface to deep water. In this study, we specifically focused on the stoichiometry of the non-refractory DOM fraction in order to check the preferential removal concept.

In the areas investigated, the water column was stratified by the upper seasonal pycnocline and, in the N-E Atlantic, by the deep pycnocline (Arhan et al., 1994), minimizing the role of vertical mixing in concentration patterns. Although DOM production and degradation processes generally occur simultaneously, decomposition predominates outside of periods of intense primary production. The periods studied (early spring or early autumn) correspond to low production, therefore relationships between DOC, DON and DOP may be assumed to essentially reflect DOM decomposition (only semi-labile DOM is involved, as previously mentioned). Our discussion was restricted to open sea stations (A2, A3 and M) where the elemental ratio for DOM and regression data sets were most complete. Figure 10 illustrates alteration of DOM by comparing composition ( $\mathrm{C}: \mathrm{N}$ and $\mathrm{C}: \mathrm{P}$ ratios for $\mathrm{DOM})$ and relative variations $(\triangle \mathrm{DOC}: \triangle \mathrm{DON}$ and $\triangle \mathrm{DOC}: \triangle \mathrm{DOP})$ when changing from the non-refractory surface pool to the deep refractory pool (for the sake of simplification, we disregarded the N:P ratios and slopes which combine the two others).

Regarding the DOC vs DON behavior, we note that the $\mathrm{C}: \mathrm{N}$ ratio of $\mathrm{nrDOM}$ in the Atlantic (stations A2 and A3) was 10-11 while mineralization in the upper layer occurred with a $\triangle \mathrm{DOC}: \triangle \mathrm{DON} \sim 20$. This indicates that carbon is preferentially removed over nitrogen during the first degradation step of nrDOM, or in other words, that nrDOM was enriched in nitrogen. Evidence of such process has been described by Abell et al. (2000) in the shallow layers of the subtropical North Pacific. In the Mediterranean, $\triangle \mathrm{DOC}: \triangle \mathrm{DON}$ in the upper layers was equally close to 20 , but was comparable there with the nrDOM C:N ratio $(\sim 19 \pm$ 3 ), which means that stoichiometry of DOM is probably not significantly altered during mineralization in the upper layers. In the deeper waters, the overall $\triangle \mathrm{DOC}: \triangle \mathrm{DON} \sim 10$ means that about two times more nitrogen was eliminated with the same amount of carbon compared to the upper layers. In the Atlantic, this mineralization stoichiometry was similar to that of the remaining, more refractory $\mathrm{nrDOM}$ which had been slightly enriched in nitrogen (hence with $\mathrm{C}: \mathrm{N}<11)$. Within the precision of elemental ratios for DOM and relative variations (regression slopes), the nrDOM which remains below the upper layer appeared to be decomposed according to its stoichiometry, i.e., with no preferential nitrogen removal. In the Mediterranean, the small amount of residual nrDOM below the thermocline, with a high $\mathrm{C}: \mathrm{N}$ ratio, most likely undergoes preferential nitrogen removal. 

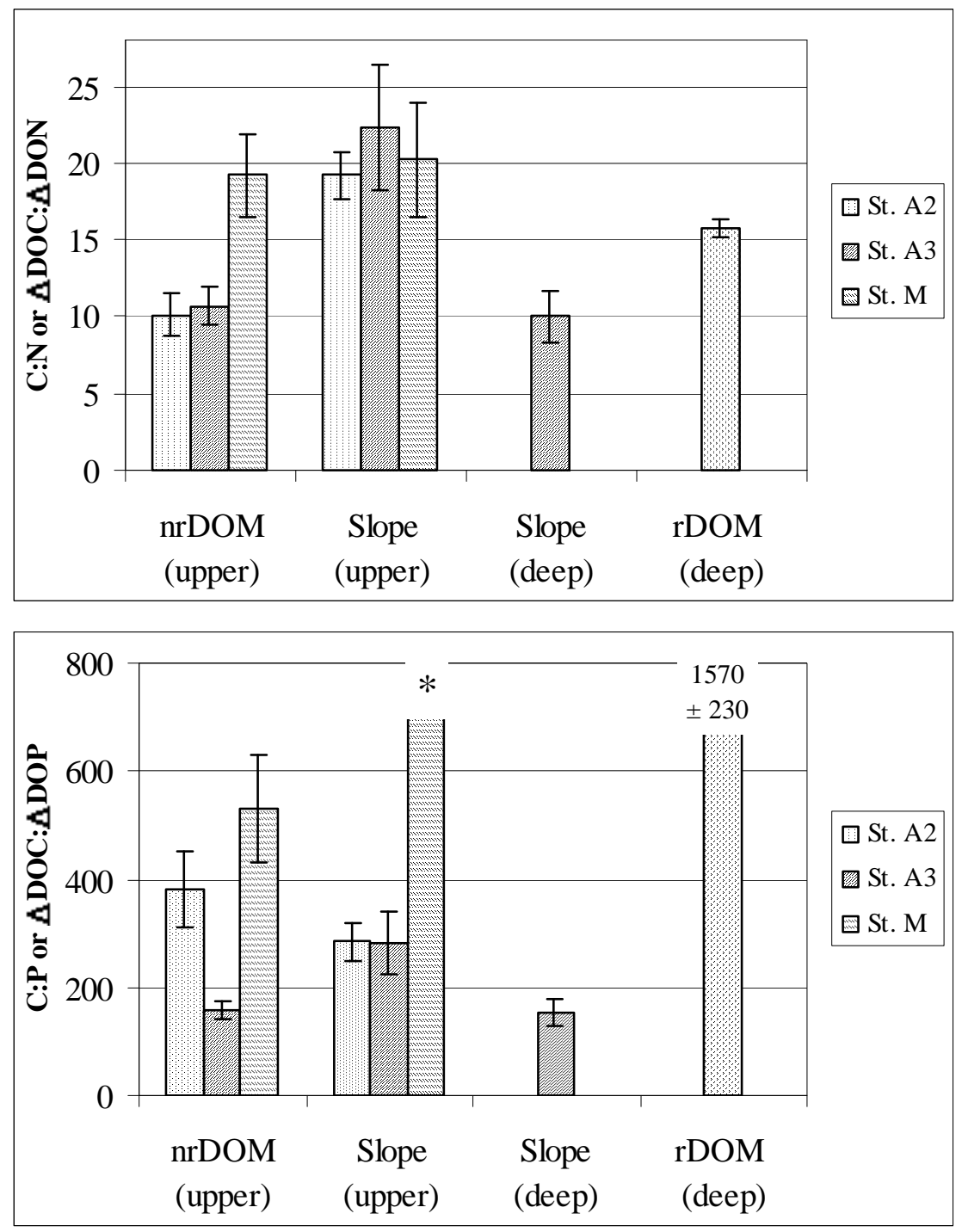

Figure 10. Comparison of C:N and C:P ratios of nrDOM and rDOM with linear regression slopes of DOC vs DON $(=\Delta \mathrm{DOC}: \triangle \mathrm{DON})$ and DOC vs DOP $(=\Delta \mathrm{DOC}: \Delta \mathrm{DOP})$ in the upper and deep layers at the open sea stations in the N-E Atlantic and the N-W Mediterranean. * This bar denotes a high, though not measurable, value of $\triangle \mathrm{DOC}: \triangle \mathrm{DOP}$.

The DOC vs DOP behavior in the Atlantic upper layers showed similar slopes $(\triangle \mathrm{DOC}: \triangle \mathrm{DOP}=280)$ at stations $\mathrm{A} 2$ and $\mathrm{A} 3$ in spite of significantly different $\mathrm{C}: \mathrm{P}$ ratios in $\mathrm{nrDOM}$. The figures seem to indicate a slight carbon enrichment $(\triangle \mathrm{DOC}: \triangle \mathrm{DOP}<\mathrm{C}: \mathrm{P}$ ratio) for early spring DOM (st. A2) against a slight phosphorus enrichment $(\triangle \mathrm{DOC}: \triangle \mathrm{DOP}>\mathrm{C}: \mathrm{P}$ ratio) for early autumn DOM (st. A3). However, because the $95 \%$ confidence intervals of the corresponding slopes and ratios overlap, these trends could not be confirmed. On average, nrDOM C:P ratios and mineralization slopes are similar ( 270 vs 280$)$, so there was no overall apparent preferential phosphorus removal during the first step of DOM degradation. In the Mediterranean, DOP was almost constant in the upper layer while DOC decreased moving downwards. This particular feature, attributed to the P-limited status of the Mediterranean, indicates preferential mineralization of carbon, hence relative phosphorus enrichment of nrDOM remaining below the thermocline in comparison with surface $\mathrm{nrDOM}$. In the deeper waters, the overall slope decreased by a factor of about 2 compared with the Atlantic upper 
layers. Since the nrDOM C:P ratio remained unchanged on average in the Atlantic upper layers, deep water degradation is assumed to occur with preferential removal of phosphorus with regard to carbon $(\triangle \mathrm{DOC}: \triangle \mathrm{DOP} \sim 150)$. In the Mediterranean, no mechanism can be inferred for deep water.

The mineralization of DOM mainly occurs through heterotrophic microbial activity (Azam and Hodson, 1977). Bacterial growth efficiency (BGE $=$ the fraction of carbon incorporated into the microbial biomass over the total amount of carbon consumed for both energy production and biomass) is an essential factor which governs the stoichiometry of DOM mineralization, and hence excretion or demand of inorganic compounds by bacteria. Considerable variability in BGE has been reported in the literature (see Carlson et al., 1999). Although a BGE of 0.5 is typical for aerobic bacteria growing on labile DOM, values of 0.10.6 have been reported in natural waters (Fenchel et al., 1998). The BGE decreases when DOM is more recalcitrant (Fenchel et al., 1998) and when bacteria are $\mathrm{N}$ - and P-limited (Carlson and Ducklow, 1996).

In surface layers, complex processes between biological activity and particulate and dissolved labile organic matter do not allow to infer a relationship between DOM mineralization and BGE from our data. In deep water, the system may be reduced essentially to DOM, as the substrate, and bacteria. Then, typical BGE can be determined for two cases, i) all consumed DON is assimilated, and ii) all consumed DOP is assimilated. Considering an average C:N:P ratios for a bacterial biomass of about 45:8:1 (Fenchel et al., 1998; Goldman et al., 1987), i.e., $\mathrm{C}: \mathrm{N}=5.6$ and $\mathrm{C}: \mathrm{P}=45$ and the average mineralization ratios (Table 5) for $\mathrm{DOM}$ of $\triangle \mathrm{DOC}: \triangle \mathrm{DON}=10$ and $\triangle \mathrm{DOC}: \triangle \mathrm{DOP}=153$, the corresponding BGE would be $\sim 0.6(5.6: 10)$ and $\sim 0.3(45: 153)$ respectively. According to the literature, BGE for recalcitrant DOM remaining below the thermocline would be in the order of 0.1 or less. Consequently, a large proportion of DON and DOP consumed with DOC must be directly mineralized by bacteria (and not by subsequent bacteria grazing).

By coupling non-refractory DOM stoichiometry and relationships between the main DOM elements in the water column our results confirm the preferential removal of phosphorus relative to carbon from the semi-labile DOM in deep water, but they do not allow us to confirm the preferential removal of nitrogen. They show that processes differ in the upper oceanic layers from those in deep waters, and that they depend on the oceanic basin, with possible preferential carbon removal.

\section{Acknowledgement}

We thank Michel Joanny and Anne-Marie Le Guellec for their assistance during the three Intersite cruises, P. Morin and G. Thoumelin for samples collected during the Gastom cruises, M. Lunven for the CTD data of the Gasprod cruise and B. Beliaeff for advice on

statistics. We are grateful to Dr. J. Sharp and two anonymous reviewers for their helpful comments.

\section{References}

Abell, J., Emerson, S., Renaud, P., 2000. Distribution of TOP, TON and TOC in the North Pacific subtropical gyre : Implication for nutrient supply in the surface ocean and remineralization in the upper thermocline. Journal of Marine Research 58, 203-222.

Alvarez-Salgado, X.A., Miller, A.E.J., 1998. Simultaneous determination of dissolved organic carbon and total dissolved nitrogen in seawater by high temperature catalytic oxidation: conditions for precise shipboard measurements. Marine Chemistry 62, 325-333. 
Aminot, A., Kérouel, R., 1990. Improvement of a commercial continuous flow method for the determination of Dissolved Organic Carbon in fresh water and seawater. Analusis 18, 289295.

Aminot, A., Kérouel, R., 1995. Reference material for nutrients in seawater : stability of nitrate, nitrite, ammonia and phosphate in autoclaved samples. Marine Chemistry 49, 221232.

Aminot, A., Kérouel, R., 1996. Stability and preservation of primary calibration solutions of nutrients. Marine Chemistry 52, 173-181.

Aminot, A., Kérouel, R., 2001. An automated photo-oxidation method for the determination of dissolved organic phosphorus in marine and fresh water. Marine Chemistry 76, 113-126.

Arhan, M., Colin de Verdière, A., Mémery, L., 1994. The eastern boundary of the subtropical North Atlantic. Journal of Physical Oceanography 24 (6), 1295-1316.

Azam, F., Hodson, R.E., 1977. Size distribution and activity of marine microheterotrophs. Limnology and Oceanography 22, 492-501.

Bada, J.L., Lee, C., 1977. Decomposition and alteration of organic-compounds dissolved in seawater. Marine Chemistry 5, 523-534.

Bauer, J.E., William, P.M., Druffel, E.R.M., 1992. 14C activity of dissolved organic fractions in the central Pacific and Sargasso Sea. Nature 357, 667-670.

Beaugrand, G, Reid, PC, Ibanez, F, Lindley, JA, Edwards, M, 2002. Reorganization of North Atlantic Marine Copepod Biodiversity and Climate. Science (Washington) 296 (5573), 1692-1694.

Benner, R., Biddanda, B., 1998. Photochemical transformations of surface and deep marine dissolved organic matter: effect on bacterial growth. Limnology and Oceanography 43(6), 1373-1378.

Berland, B.R., Bonin D.J., Maestrini, S.Y., 1980. Azote ou phosphore? Considérations sur le "paradoxe nutritionnel" de la Méditerranée. Oceanologica Acta 3 (1), 135-142.

Berman, T., Chava, S., 1999. Algal growth on organic compounds as nitrogen source. Journal of Plankton Research 21, 1423-1437.

Björkman, K., Thomson-Bulldis, A.L., Karl, D.M. 2000. Phosphorus dynamics in the North Pacific tropical gyre. Aquatic microbial Ecology 22, 185-198.

Bronk, D.A., 2002. Dynamics of DON. In: Hansell, D.A., Carlson, C.A. (Eds), Biogeochemistry of marine dissolved organic matter. Academic Press, Amsterdam, Boston, pp. 153-247.

Bronk, D.A., Lomas, M.W., Glibert, P.M., Schukert, K.J., Sanderson, M., 2000. Total dissolved nitrogen analysis: comparison between the persulfate, UV and high temperature oxidation methods. Marine Chemistry 69, 163-178.

Carlson, C.A., Ducklow, H.W., 1995. Dissolved organic carbon in the upper ocean of the central equatorial Pacific Ocean, 1992; Daily and fine-scale vertical variations Deep-Sea Research Part II 42, 639-656.

Carlson, C.A., Ducklow, H.W., 1996. Growth of bacterioplankton and consumption of dissolved organic carbon in the Sargasso Sea. Aquatic Microbial Ecology 10 (1), 69-85.

Carlson, C.A., Ducklow, H.W., Michaels, A. F., 1994. Annual flux of dissolved organic carbon from the euphotic zone in the northwestern Sargasso Sea. Nature 371, 405-408.

Carlson, C.A., Bates, N.R., Ducklow, H.W., Hansell, D.A, 1999. Estimation of bacterial respiration and growth efficiency in the Ross Sea, Antartica. Aquatic Microbial Ecology 19, 229-244.

Cauwet, G., Sempéré, R., Saliot, A., 1990. Carbone organique dissous dans l'eau de mer: confirmation de la sous-estimation antérieure. Comptes-Rendus de l'Académie des Sciences de Paris 311, 1061-1066. 
Cauwet, G., Miller, A., Brasse, S., Fengler, G., Mantoura, R.F.C., Spitzy, A., 1997. Dissolved and particulate organic carbon in the western Mediterranean Sea. Deep-Sea Research Part II 44 (3-4), 769-779.

Christensen, J.P., Packard, T.T., Dortch, F.Q., Minas, H.J., Gascard, J.C., Richez, C., Garfield, P.C., 1989. Carbon oxidation in the deep Mediterranean Sea: evidence for dissolved organic carbon source. Global Biogeochemical Cycles 3, 315-335.

Clark, L.L., Ingall, E.D., Benner, R., 1998. Marine phosphorus is selectively remineralized. Nature 393, 426.

Clark Kolowith, L., Ingall, E.D., Benner, R., 2001. Composition and cycling of marine organic phosphorus. Limnology and Oceanography 46 (2), 309-320.

Cochran, W.G., 1977. Sampling techniques. J. Wiley and Son, New York, 428 pp.

Copin-Montégut, G., Avril, B., 1993. Vertical distribution and temporal variation of dissolved organic carbon in the North-Western Mediterranean Sea. Deep-Sea Research Part I 40 (10), 1963-1972.

Cotner, J.B., Ammerman, J.W., Peele, E.R., Bentzen, E., 1997. Phosphorus-limited bacterioplankton growth in the Sargasso Sea. Aquatic Microbial Ecology 13, 141-149.

Doval, M.D., Perez, F.F., Berdalet, E., 1999. Dissolved and particulate organic carbon and nitrogen in the Northwestern Mediterranean. Deep-sea Research Part I 46, 511-527.

El Sayed, M.A., Aminot, A., Kérouel, R., 1994. Nutrients and trace metal in the northwestern Mediterranean. Continental Shelf Research 14 (5), 507-530.

Emerson, S., Quay, P., Karl, D.M., Winn, C., Tupas, L., Landry, M., 1997. Experimental determination of the organic carbon flux from open-ocean surface waters. Nature 389, 951954.

Fasham, M.J.R., Boyd, P.W., Savidge, G., 1999. Modeling the relative contribution of autotrophs and heterotrophs to carbon flow at a Lagrangian JGOFS station in the Northeast Atlantic: the importance of DOC. Limnology and Oceanography 44 (1), 80-94.

Fenchel, T., King, G.M., Blackburn, T.H., 1998. Bacterial biogeochemistry: the ecophysiology of mineral cycling (2nd ed). Academic Press, San Diego, London, Boston, $307 \mathrm{pp}$.

Ferrari, G.M., 2000. The relationship between chromophoric dissolved organic matter and dissolved organic carbon in the European Atlantic coastal area and in the West Mediterranean Sea (Gulf of Lions). Marine Chemistry 70, 339-357.

Goldman, J.C., Caron, D.A., Dennett, M.R., 1987. Regulation of gross growth efficiency and ammonium regeneration in bacteria by substrate $\mathrm{C}: \mathrm{N}$ ratio. Limnology and Oceanography 32 (6), 1239-1252.

Hansell, D.A., Carlson, C.A., 1998. Deep ocean gradients in concentration of dissolved organic carbon. Nature 395, 263-266.

Hobson, L.A., Menzel, D.W., 1969. The distribution and chemical composition of organic particulate matter in the sea and sediments off the east coast of South America. Limnology and Oceanography 14 (1), 159-163.

Hopkinson Jr, C.S., Fry, B., Nolin, A.L., 1997. Stoichiometry of dissolved organic matter dynamics on the continental shelf of the northeastern USA. Continental Shelf Research 17 (5) 473-489.

Hunt A.P., Parry, J.D., Hamilton-Taylor, J., 2000. Further evidence of elemental composition as an indicator of the bioavailability of humic substances to bacteria. Limnology and Oceanography 41 (1), 237-241.

Hydes, D.J., Le Gall, A.C., Miller A.E.J., Brockmann, U., Raabe, T., Holley, S., AlvarezSalgado, X., Antia, A., Balzer, W., Chou, L., Elskens, M., Helder, W., Joint, M., Orren, M., 2001. Supply and demand of nutrients and dissolved organic matter at and across the 
NW European shelf break in relation to hydrography and biogeochemical activity. DeepSea Research Part II 48 (14-15), 3023-3047.

Kähler, P., Koeve, W., 2001. Marine dissolved organic matter: can its C: N ratio explain carbon overconsumption. Deep-Sea Research Part I 48, 49-62.

Karafistan, A., Martin, J.M., Rixen, M., Beckers, J.M., 2002. Space and time distribution of phosphate in the Mediterranean Sea. Deep-Sea Research Part I 49, 67-82.

Karl, D.M., Björkman, K.M., 2002. Dynamics of DOP. In: Hansell, D.A., Carlson, C.A. (Eds), Biogeochemistry of marine dissolved organic matter. Academic Press, Amsterdam, Boston, pp. 249-366.

Karl, D.M., Tien, G, 1997. Temporal variability in dissolved phosphorus concentrations in the sub-tropical North Pacific Ocean. Marine Chemistry 56, 77-96.

Kérouel, R., Aminot, A., 1996. Model compounds for the determination of organic and total phosphorus dissolved in natural waters. Analytica Chimica Acta 318, 385-390.

Kérouel, R., Aminot, A, 1997. Fluorimetric determination of ammonia in sea and estuarine waters by direct segmented flow analysis. Marine Chemistry 57, 265-275.

Kirchman, D.L., Lancelot, C., Fasham, M, Legendre, L., Radach, G., Scott, M., 1993. Dissolved organic material in biogeochemical models of the ocean. In Evans, G.T., Fasham, M.J.R. (Eds), Towards a model of Ocean Biogeochemical Processes, Serie I : Global Environmental Change, vol. 10, 209-225. Berlin.

Kirchman, D.L., Susuki Y., Garside, C., Ducklow, H.W., 1991. High turnover rates of dissolved organic carbon during a spring phytoplankton bloom. Nature 352, 612-614.

Koroleff, F., 1983. Determination of phosphorus. In: Grasshoff, K., Ehrhardt, M., Kremling, F. (Eds), Methods of seawater analysis (2nd ed). Verlag-Chemie, Weinheim, New York, pp. 125-139.

Körtzinger, A., Koeve, W., Kähler, P., Mintrop, L., 2001. C:N ratio in the mixed layer during the productive season in the northeast Atlantic Ocean. Deep-Sea Research Part I 48, 661688.

Labry, C., Herbland, A., Delmas, D., 2002. The role of phosphorus on planktonic production of the Gironde plume waters in the bay of Biscay. Journal of Plankton Research 24 (2), 97 117.

Lacombe, H., 1975. Aperçu sur l'apport à l'océanographie physique des recherches récentes en Méditerranée. Newsletter of the cooperative investigations in the Mediterranean, special issue 7, 5-25.

Lacombe, H., Tchernia, P., Gamberoni, L., 1985. Variable bottom water in the Western Mediterranean basin. Progress in Oceanography 14, 319-338.

Lacombe, H., Tchernia, P., 1972. Hydrological features and circulation of Mediterranean waters. In: Stanley, D.J. (Ed.), The Mediterranean Sea: A Natural Sedimentation Laboratory. Dowden, Hutchinson and Ross, Stroudsberg, PA, pp. 25-36.

Loder, T.C., Glibert, P.M., 1977. Blank and salinity corrections for automated nutrient analysis of estuarine and sea waters. UNH Sea Grant No. UNH-5G-JR-101 and WHOI No. 3897, $29 \mathrm{pp}$.

Loh, A.N., Bauer, J.E., 2000. Distribution, partitioning and fluxes of dissolved and particulate organic C, N and P in the eastern North Pacific and Southern Oceans. Deep-Sea Research Part II 47, 2287-2316.

Martin, J.M., Elbaz-Poulichet, F., Guieu, C., Loye-Pilot, M.D., Han, G., 1989. River versus atmospheric input to the western Mediterranean: a summary. In: Martin, J.M., Barth, H. (Eds.), EROS 2000, First Workshop on the North-West Mediterranean Sea, Commission of the European Communities, Water Pollution Research Reports 13, 423-434.

Massart, D.L., Vandeginste, B.G.M., Deming, S.N., Michotte, Y., Kaufman, L. 1988 Chemometrics: a textbook, Elsevier, Amsterdam, 488 pp. 
McGill, D.A., 1965. The relative supplies of phosphate, nitrate and silicate in the Mediterranean Sea. Commission Internationale pour l'Exploration Scientifique de la Mer Méditerranée, Rapports et Procès Verbaux des Réunions 18, 737-744.

Menzel, D.W., 1974. Primary productivity, dissolved organic matter, and the sites of oxidation of organic matter. In: Goldberg, E.D. (Ed), The sea (Vol. 5), Wiley Interscience, New York, pp. 659-678.

Millero, F.J., 1996. Chemical Oceanography. 2nd ed. CRC Press Inc., Boca Raton, 469 pp.

Mopper, K., Zhou, X., Kieber, R.J., Kieber, D.J., Sikorski, R.J., Jones, R.D., 1991. Photochemical degradation of dissolved organic carbon and its impact on the oceanic carbon cycle. Nature 353, 60-62.

Moran, M.A., Zepp, R.G., 1997. Role of photoreactions in the formation of biologically labile compounds from dissolved organic matter. Limnology and Oceanography 42 (6), 13071316.

Myklestad, S., Haug, A., 1972. Production of carbohydrates by the marine diatom Chaetoceros affinis var. Willei (Gran) Hustedt I. Effect of the concentration of nutrients in the culture medium. Journal of Experimental Marine Biology and Ecology 9, 125-136.

Myklestad, S., Holm-Hansen, O., Vårum, K.M., Volcani, B.E., 1989. Rate of release of extracellular amino acids and carbohydrates from the marine diatom Chaetoceros affinis. Journal of Plankton Research 11, 763-773.

Nagata, T., Kirchman, D.L., 1991. Release of dissolved free and combined amino acids by bacterivorous marine flagellates. Limnology and Oceanography 36 (3), 433-443.

Ogura, N., 1975. Further studies on decomposition of dissolved organic matter in coastal seawater. Marine Biology 13, 101-111.

OSPAR Commission, 2000. Quality Status Report 2000. OSPAR Commission, London, 108 + vii pp.

Peltzer, E.T., Brewer, P.G.,1993. Some practical aspects of measuring DOC sampling artifacts and analytical problems with marine samples. Marine Chemistry 41, 243-252.

Peltzer, E.T., Fry, B., Doering, P.H., McKenna, J.H., Normann, B., Zweifel, U.L., 1996. A comparison of methods for the measurement of dissolved organic carbon in natural waters. Marine Chemistry 54, 85-96.

Pomeroy, L.R., 1974. The oceans food web, a changing paradigm. Bioscience 24, 499-504.

Raimbault, P., Pouvesle, W., Diaz, F., Garcia, N., Sempere, R., 1999. Wet-oxidation and automated colorimetry for simultaneous determination of organic carbon, nitrogen and phosphorus dissolved in seawater. Marine Chemistry 66 (3-4), 161-169.

Redfield, A.C., Ketchum, B.H., Richards, F.A., 1963. The influence of organisms on the composition of sea water. In: Hill, M.N. (Ed.), The Sea (Vol 2), Wiley Interscience, New York, pp. 26-77.

Riley, J.P., Chester, R., 1971. Introduction to marine chemistry. Academic Press, London, New York, 465 pp.

Ridal, J.J., Moore, R.M., 1990. A Re-examination of the measurement of dissolved organic phosphorus in seawater. Marine Chemistry 29, 19-31.

Ridal, J.J., Moore, R.M., 1992. Dissolved organic phosphorus concentrations in the northeast subarctic Pacific Ocean. Limnology and Oceanography 37 (5), 1067-1075.

Rodwell, M.J., Rowell, D.P., Folland, C.K., 1999. Ocean forcing of the wintertime North Atlantic Ocillation and European climate. Nature 398, 320-323.

Sambrotto, R.N., Savidge, G.R., Robinson, C., Boyd, P., Takashi, T., Karl, D.M., Langdon, C., Chipman, D., Marra, J., Codispoti, L., 1993. Elevated consumption of carbon relative to nitrogen in the surface ocean. Nature 363, 248-250.

Sanders, R., Jickells,T., 2000. Total organic nutrients in Drake Passage. Deep-Sea Research Part I 47, 997-1014. 
Schell, D.M., 1974. Uptake and regeneration of free amino acids in marine waters of Southeast Alaska. Limnology and Oceanography 19 (2), 260-270.

Sharp, J.H., 1993. The dissolved organic carbon controversy, an update. Oceanography 6 (2), 45-50.

Sharp, J.H., 1997. Marine dissolved organic carbon: Are the older values correct? Marine Chemistry 56, 265-277.

Sharp, J.H., Benner, R., Bennett, L., Carlson, C.A., Dow, R., Fitzwater, S.E., 1993. A reevaluation of high-temperature combustion and chemical oxidation measurements of dissolved organic carbon in seawater. Limnology and Oceanography 38, 1774-1782.

Sharp, J.H., Benner, R., Bennett, L., Carlson, C.A., Fitzwater, S.E., Peltzer, E.T., Tupas, L.M., 1995. Analyses of dissolved organic carbon in seawater: the JGOFS EqPak methods comparison. Marine Chemistry 48, 91-108.

Sharp, J.H., Carlson, C.A., Peltzer, E.T., Castle-Ward, D.M., Savidge, K.B., Rinker, K.R., 2002. Final dissolved organic carbon broad community intercalibration and preliminary use of DOC reference materials. Marine Chemistry 77, 239-253.

Solorzano, L., Sharp, J. H., 1980. Determination of total dissolved nitrogen in natural waters. Limnology and Oceanography 25 (4), 751-754.

Staats, N., Stal L.J., Mur, L.R., 2000. Exopolysaccharide production by the epipelic diatom Cylindrotheca closterium: effects of nutrient conditions. Journal of Experimental Marine Biology and Ecology 249 (1), 13-27.

Sugimura, Y., Suzuki, Y., 1988. A high temperature catalytic oxidation method for the determination of non-volatile dissolved organic carbon in seawater by direct injection of a liquid sample. Marine Chemistry 24, 105-131.

Sun, L., Perdue, E.M., Meyer, J.L., Weis, J., 1997. Use of elemental composition to predict bioavailability of dissolved organic matter in a Georgia river. Limnology and Oceanography 42 (4), 714-721.

Suzuki, Y., Sugimura, Y., Itoh T., 1985. A catalytic oxidation method for the determination of total nitrogen dissolved in seawater. Marine Chemistry 16, 83-97.

Taylor, J.K., 1990. Quality assurance of chemical measurements. Lewis Publishers, Inc., USA, $328 \mathrm{pp}$.

Toggweiler, J.R., 1988. Deep-sea carbon, a burning issue. Nature 334, 468.

Toggweiler, J.R., 1989. Is the downward dissolved organic matter (DOM) flux important in carbon transport? In: Berger, W.H., Smetacek, V.S, Wefer, G. (Eds), Productivity in the ocean: present and past. Wiley, New York, pp. 65-83.

Tréguer, P., Le Corre, P., 1975. Manuel d'analyse des sels nutritifs dans l'eau de mer. Université de Bretagne Occidentale, Brest, France, 110 pp.

Tupas, L.M., Popp, B.N., Karl, D.M., 1994. Dissolved organic carbon in oligotrophic waters: experiments on sample preservation, storage and analysis. Marine Chemistry 45, 207-216.

Vangrieshem, A, 1985. Hydrologie et circulation profonde. In: Laubier, L., Monniot, C. (Eds), Peuplements profonds du Golfe de Gascogne, Campagne Biogas. IFREMER, Service Documentation-Publications, Brest, France, pp. 43-70.

Vidal, M., Duarte, C.M., Agusti, S., 1999. Dissolved organic nitrogen and phosphorus pools and fluxes in the central Atlantic Ocean. Limnology and Oceanography 44 (1), 106-115.

Walsh, T.W., 1989. Total dissolved nitrogen in seawater: a new high temperature combustion method and a comparison with photo-oxidation. Marine Chemistry 26, 295-311.

Webb, K.L., Johannes, R.E., 1967. Studies of the release of dissolved free amino acids by marine zooplankton. Limnology and Oceanography 12 (3), 376-382.

Williams, P.J le B., 1995. Evidence for the seasonal accumulation of carbon-rich dissolved organic material, its scale in comparison with changes in particulate material and the consequential effect on net $\mathrm{C} / \mathrm{N}$ assimilation ratios. Marine Chemistry 51, 17-29. 
Williams, P.M., Druffel, E.R.M., 1988. Dissolved organic matter in the ocean: Comments on a controversy. Oceanography 1 (1), 14-17.

Williams, P.M., Bauer, J.E., Robertson, K.J., Wolgast, D.M., Occelli, M.L., 1993. Report on DOC and DON measurements made at Scripps Institution of Oceanoraphy, 1988-1991. Marine Chemistry 41, 271-281.

Wu, J., Sunda, W., Boyle, E.A., Karl, D.M., 2000. Phosphate depletion in the western North Atlantic. Science 289, 759-762.

Wüst, G., 1961. On the vertical circulation of the Mediterranean Sea. Journal of Geophysical Research 66 (10), 3261-3271. 